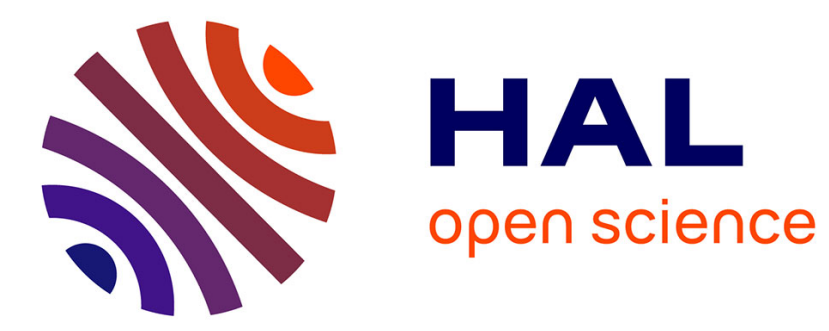

\title{
Recent findings on phenoloxidases in bivalves
}

\author{
A. Luna-Acosta, Marine Breitwieser, T. Renault, Hélène Thomas-Guyon
}

\section{To cite this version:}

A. Luna-Acosta, Marine Breitwieser, T. Renault, Hélène Thomas-Guyon. Recent findings on phenoloxidases in bivalves. Marine Pollution Bulletin, 2017, 122 (1-2), pp.5 - 16. 10.1016/j.marpolbul.2017.06.031 . hal-01680264

\section{HAL Id: hal-01680264 \\ https: / hal-univ-rochelle.archives-ouvertes.fr/hal-01680264}

Submitted on 3 May 2019

HAL is a multi-disciplinary open access archive for the deposit and dissemination of scientific research documents, whether they are published or not. The documents may come from teaching and research institutions in France or abroad, or from public or private research centers.
L'archive ouverte pluridisciplinaire HAL, est destinée au dépôt et à la diffusion de documents scientifiques de niveau recherche, publiés ou non, émanant des établissements d'enseignement et de recherche français ou étrangers, des laboratoires publics ou privés. 


\title{
Marine Pollution Bulletin
}

\section{Review}

\section{Recent findings on phenoloxidases in bivalves}

\author{
A. Luna-Acosta ${ }^{\mathrm{a}, \mathrm{c}, *}$, Marine Breitwieser ${ }^{\mathrm{a}, * *}, \mathrm{~T}$. Renault ${ }^{\mathrm{b}}, \mathrm{H}$. Thomas-Guyon ${ }^{\mathrm{a}}$ \\ a Littoral Environnement et Sociétés (LIENSS), UMR 6250, CNRS-Université de La Rochelle, 2 rue Olympe de Gouges - F-17042, La Rochelle Cedex 01, France \\ b Ifremer, Département Ressources biologiques et environnement (RBE), 44311 Nantes Cedex 03, France \\ c Departamento de Ecología y Territorio, Facultad de Estudios Ambientales y Rurales (FEAR), Pontificia Universidad Javeriana, Transv. 4 No. $42-00$, Bogota, Colombia
}

\begin{tabular}{|c|c|}
\hline & A B S T R A C T \\
\hline $\begin{array}{l}\text { Keywords: } \\
\text { Molluscs } \\
\text { Phenoloxidase } \\
\text { Laccase } \\
\text { Ecological biomarker } \\
\text { Environmental stress }\end{array}$ & $\begin{array}{l}\text { The production of melanin is a complex process involving biochemical cascades, such as the pro-phenoloxidase } \\
\text { (proPO) system, and enzymes, such as phenoloxidases (POs). Different studies have shown a strong correlation } \\
\text { between the decrease in PO activities and the occurrence of diseases in bivalve invertebrates, leading to mor- } \\
\text { talities in the host. Results of these studies suggest that POs could play a fundamental role in defense me- } \\
\text { chanisms in bivalves. This article reviews the fundamental knowledge on the proPO system in bivalves and the } \\
\text { methods used to assess PO activities. Finally, this is the first report on the major findings of laboratory and field } \\
\text { studies that indicate that a type of PO in bivalves, the laccase enzyme, is inducible and involved in the 1) } \\
\text { immune 2) antioxidant and 3) detoxification roles in bivalves, and might be an ecological potential biomarker of } \\
\text { environmental stress. }\end{array}$ \\
\hline
\end{tabular}

\section{Introduction}

Phenoloxidases (POs, EC 1.14.18.1) are the key enzymes of an ubiquitous biochemical cascade responsible for the production of melanin. This biochemical cascade plays a role in immune defenses, wound healing, encapsulation and melanisation, as well as in self/non-self recognition mechanisms in invertebrates (Cerenius et al., 2008). In vitro studies have shown a bactericidal effect of PO activities in invertebrates, such as the tobacco hornworm Manduca sexta (Zhao et al., 2007), the mealworm beetle Tenebrio molitor (Kan et al., 2008), the freshwater crayfish Pacifastacus leniusculus (Cerenius et al., 2010), the Pacific oyster Crassostrea gigas (Luna-Acosta et al., 2011a), the scallop Chlamys farreri (Zhou et al., 2012), the Manila clam Venerupis philippinarum (Le Bris et al., 2013), the bivalve mollusc Scrobicularia plana (Buffet et al., 2014) and the smooth venus clam Callista chione (Matozzo and Bailo, 2015). These results suggest that POs have a protective role on bacterial infection. Moreover, different studies have shown a strong correlation between the decrease in PO activities in the Sydney rock oyster Saccostrea glomerata and the occurrence of Queensland disease (QX disease), caused by the parasite Marteilia sydneyi and leading to mortality in the host (for review, see Raftos et al., 2014). These results suggest that POs have a protective role on parasite infection. It has also been suggested that PO activities may be involved in antiviral defenses in invertebrates (Terenius et al., 2007; Xing et al., 2008; Renault et al.,
2011). Recently, studies investigated the immune responses of phenoloxidase (increased expression and spatio-temporal evolution of enzymes' activities post-infection) in the manila clam Venerupis philippinarum challenged with Vibrio tapetis in order to better understand the combined effect of temperature and two $V$. tapetis strains in the Manila clam Venerupis philippinarum (Richard et al., 2015; Le Bris et al., 2015).

Noxious effects in immune defense mechanisms, such as POs, due to the presence of stressors in the environment, such as chemical contaminants, can induce the occurrence and/or increase of diseases. Unfortunately, development of human activities leads to chronic pollution of the environment by a mixture of inorganic (metals) and organic (pesticides, hydrocarbons, phytosanitaries) contaminants. The use of biomarkers allows observation of the impact of chemical contaminants on coastal species while the physiological dysfunctions caused by the exposure to chemical contaminants. These dysfunctions can be early diagnosed, by studying biomarker responses at the gene or protein level (Amiard-Triquet et al., 2006). Early diagnosis means observing dysfunctions before any tissue damage or any damage on main biological functions is detected. Biomarkers can be classified in three types: biomarkers of exposure, biomarkers of effect and biomarkers of susceptibility (Manahan, 2003). Biomarkers of exposure indicate the presence of a contaminant inside the organism, due to an interaction of this contaminant with biological molecules. Biomarkers of effect indicate the toxic or sublethal effect of the contaminant on the organism.

*Correspondence to: A. Luna-Acosta, Departamento de Ecología y Territorio, Facultad de Estudios Ambientales y Rurales, Pontificia Universidad Javeriana, Transv. 4 No. 42-00, Bogotá, Colombia.

*** Corresponding author.

E-mail addresses: aluna1508@yahoo.com (A. Luna-Acosta), marine.breitwieser@univ-lr.fr (M. Breitwieser). 
However, the definition of these classes varies depending on different authors. So, certain ecotoxicologists prefer the terminology proposed by De Lafontaine et al. (2000) and that will be used in this manuscript, contrasting biomarkers of defense and biomarkers of damage.

Biomarkers of defense correspond to mechanisms that allow the organism to survive in a deteriorated environment, and consequently, have a positive effect on their health. The energy allocated to these defense mechanisms or "cost of tolerance" to the presence of the contaminant in the organism will be retrieved from the energy allocated to the basal metabolism, growth and/or reproduction (fitness), which can impair the organism in the long term (Holloway et al., 1990). Some examples of biomarkers of defense are: phase II enzymes (glutathion-Stransferase, MXSM), metallothioneins, antioxidant defense enzymes and molecules (superoxide dismutase, catalase, glutathion peroxidase, glutathion), heat shock proteins, etc. (Amiard-Triquet et al., 2006).

Biomarkers of damage correspond to biological damages in the organism leading to an impairment in the fitness of the organism. Some examples of biomarkers of damage are: acetylcholinesterase, vitellogenin, lysosomal membrane stability, lipid peroxidation, DNA damages and adducts, molecular markers (cortisol, retinol), inmunological markers (\% of phagocytosis), histological markers (histopathological index), etc. (Amiard-Triquet et al., 2006).

Among proteins that can be modulated by the presence of contaminants in the environment, different authors have shown that PO activities in bivalve molluscs can be modulated by inorganic (Gagnaire et al., 2004; Chakraborty et al., 2010; Cong et al., 2013; Haberkorn et al., 2014; Buffet et al., 2013; Buffet et al., 2014) and organic contaminants (Bado-Nilles et al., 2009a, 2009b; Bado-Nilles et al., 2010; Bianchi et al., 2014; Díaz-Resendiz et al., 2014; Luna-Acosta et al., 2011b; Milinkovitch et al., 2015a; Breitwieser et al., 2016). In addition, a gene coding for a laccase-type PO has been identified in C. gigas (Renault et al., 2011) and modulation of the expression of this gene has been observed, following exposure of $C$. gigas to hydrocarbons (BadoNilles et al., 2010) and to the pesticide diuron (Luna-Acosta et al., 2012). This type of noxious effects in immune defense mechanisms can induce in the organism the occurrence and/or increase of diseases.

The present work aims to review and discuss published data on PO activity assessment, gene expression and potential roles in bivalve molluscs. To date, most of the work published on PO activity in marine bivalves is focused on the roles of POs in immune defense mechanisms. However, recent studies suggest an ecological relevance of these POs, an especially of laccases, as a novel biomarker for marine environmental pollution studies. In this context, we will analyze data relative to studies on POs, by exposing new hypotheses regarding their potential roles in these invertebrate organisms.

\section{Molecular and biochemical aspects}

The first studies on POs were carried out in fungi, more than a century ago [for review, see (Mayer, 2006)]. However, isolation experiments of proteins started only 42 years later, revealing different functional and structural properties of POs (Mayer, 2006).

POs are copper-binding metalloproteins. As oxidoreductases, they catalyze the oxidation of phenolic compounds in the presence of oxygen $\left(\mathrm{O}_{2}\right)$. One of the main difficulties concerning the enzymatic group of POs are approximations found in the literature, since the terms "tyrosinases", "phenoloxidases" and "catecholases" are often used as synonyms (Solomon et al., 1996; Claus and Decker, 2006) and tyrosinases and POs possess the same EC number.

However, based on their activity, there are three distinct types of enzymes in the group of POs (Walker and Ferrar, 1998): 1) tyrosinases (EC 1.14.18.1), 2) catecholases (EC 1.10.3.1) and 3) laccases (EC 1.10.3.2). All three groups catalyze the oxidation of o-diphenols. This means that the three groups possess catecholase (or diphenoloxidase) activity. However, only tyrosinases catalyze the orhtohydroxylation of monophenols. This means that only tyrosinases possess a cresolase (or

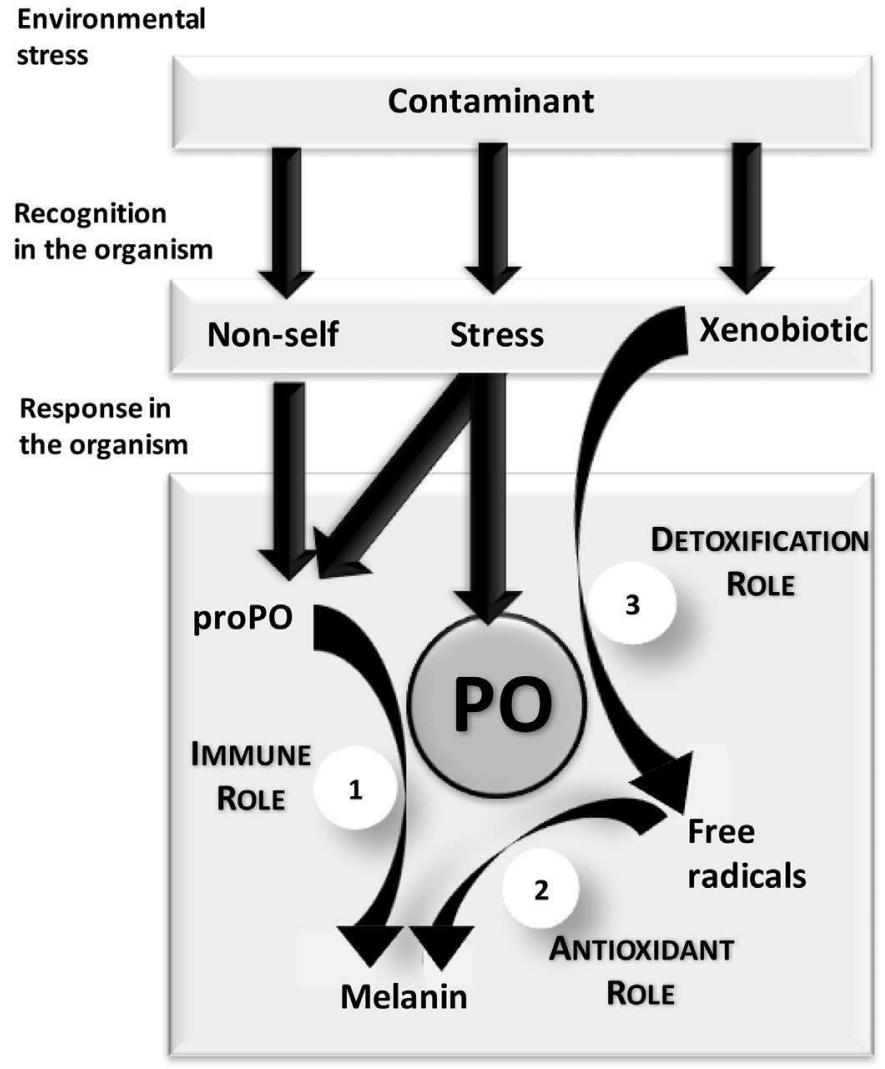

Fig. 1. Potential roles of POs in bivalve invertebrates. Contaminants present in the en vironment can induce a stress and be recognized as a foreign biological or chemical agent, or as other type of stressor. Therefore, bivalves will activate different defense mechanisms to ensure the maintenance of their homeostasis. In this context, POs could play an immune, antioxidant and/or detoxification role.

monophenoloxidase) activity. And, on the other hand, only laccases catalyze the oxidation of $\mathrm{m}$ - and $\mathrm{p}$-diphenols and other compounds, such as aromatic amines. This means that only laccases possess a laccase activity (Fig. 1). Therefore, «tyrosinases», «phenoloxidases» and «catecholases» do not necessarily possess the same type of enzyme activities and therefore these terms should not be used as synonyms, to avoid ambiguity. (See Figs. 2 and 3.)

PO size and form vary depending on the phylum and the organism: in vertebrates, tyrosinases are dimeres while in invertebrates, POs are monomeres or oligomeres (from dimeres to pentameres; Renwrantz et al., 1996). The molecular weight of POs has been determined with chromatographic exclusion techniques or with electrophoresis under denaturating conditions. The molecular weight varies from 10 to $400 \mathrm{kDa}$ and each monomer is generally 40 to $45 \mathrm{kDa}$. In bivalves, the molecular weight of proteins possessing PO activity varies from 10 to $381 \mathrm{kDa}$ (Table 1).

In one hand, tyrosinases are transmembrane proteins in humans and mice; they containing a signal peptide and a transmembrane region, e.g. Decker et al. (2007). On the other hand, the presence of a signal peptide is unlikely in arthropods and insects (Cerenius et al., 2008). In fact, only the active site is likely to be conserved in the genes of mammals, invertebrates, fungi and bacteria (Decker and Terwillinger, 2000). Generally, the active site possesses two copper-binding regions called $\mathrm{CuA}$ and $\mathrm{CuB}$. In these regions, each copper atom is coordinated by three histidine residues (Decker and Terwillinger, 2000). The gene coding for a laccase 1 identified in $C$. gigas showed 3 amino acid regions sharing a high homology with conserved Cu-oxidase domains (Renault et al., 2011) and the gene coding for a tyrosinase 1 identified in C. gigas showed a typical copper-binding domains and a signal peptide (Huan et al., 2013). A gene coding for a tyrosinase has also been reported in 


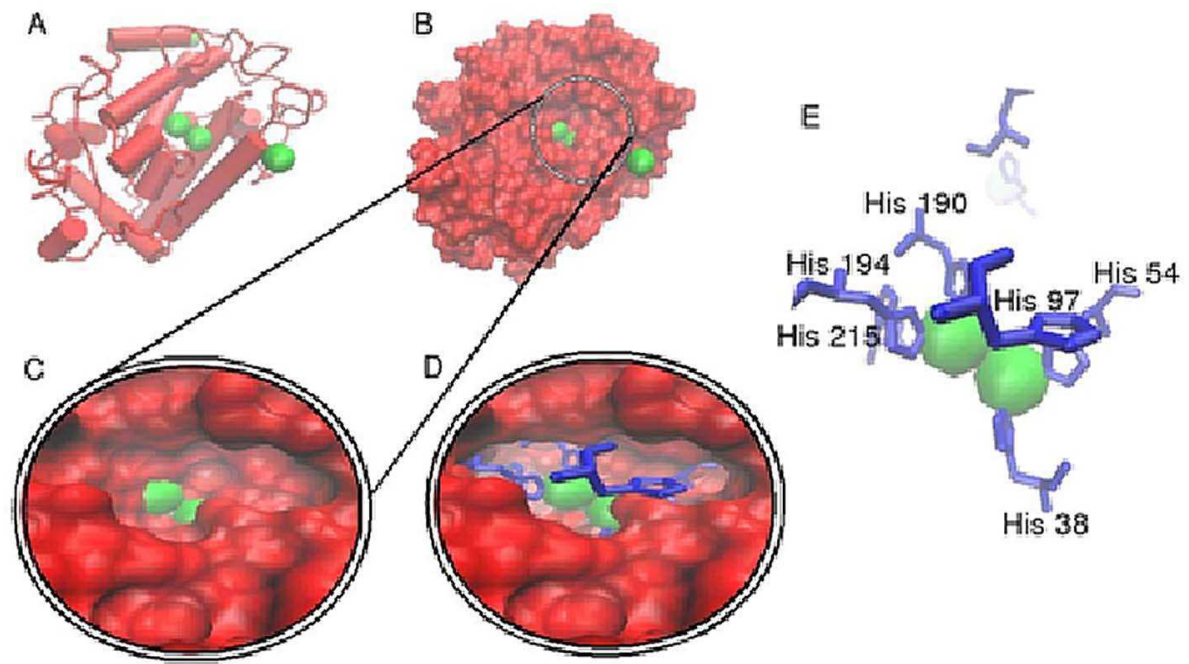

Fig. 2. Crystal structure of a phenoloxidase. According to Matoba et al. (2006). Tyrosinase Streptomyces sp. has been crystallized, combined with a protein called "caddie" that seems to be involved in copper transport to the bottom of the active site of the enzyme. Only the tyrosinase molecule is shown. In green in the figure: copper atoms; in red: the molecular surface; in blue: the amino acid histidine. The active site of the protein is localized to a pilus, formed on the surface of the molecule (C and D). Each copper atom at the active site is complexed by three histidine residues (E). (For interpretation of the references to colour in this figure legend, the reader is referred to the web version of this article.)

the Pearl oyster Pinctada fucata by Zhang et al., 2006 (GenBank accession no. DQ112679), while several genes encoding laccases have been reported in the same species through the complete sequencing of Pacific oyster genome (Martin-Gomez et al., 2012). A partial gene encoding a laccase 1 has also been described in the European flat oyster, Ostrea edulis (Martin-Gomez et al., 2012). These data reveal that only for a limited number of bivalve species, gene sequences coding for POs are available in GenBank. Furthermore, a recent review explores the use of -omic tools of disease processes in marine bivalves to better understand the environment-host-pathogen interactions in commercial and ecological bivalves (Gómez-Chiarri et al., 2015).

\section{Tissue localization}

In vertebrates, POs are only active in specialized organelles: the pigmentary epithelium of the retina and melanocytes (Riley, 1997). In invertebrates such as bivalves, PO activities have been detected in the eggs (Bai et al., 1997), in early stages of the Pacific oyster ("embryos" and larvae) (Thomas-Guyon et al., 2009), haemocytes and plasma (Gagnaire et al., 2004; Cong et al., 2005; Jordan and Deaton, 2005; Nagai et al., 2007; Luna-Gonzalez et al., 2003; Hellio et al., 2007; LunaAcosta et al., 2010a; Luna-Acosta et al., 2011c; Matozzo and Bailo, 2015), gills (Malanga and Young, 1978; Jing et al., 2006; Luna-Acosta et al., 2011c), digestive gland (Jing et al., 2006; Luna-Acosta et al.,

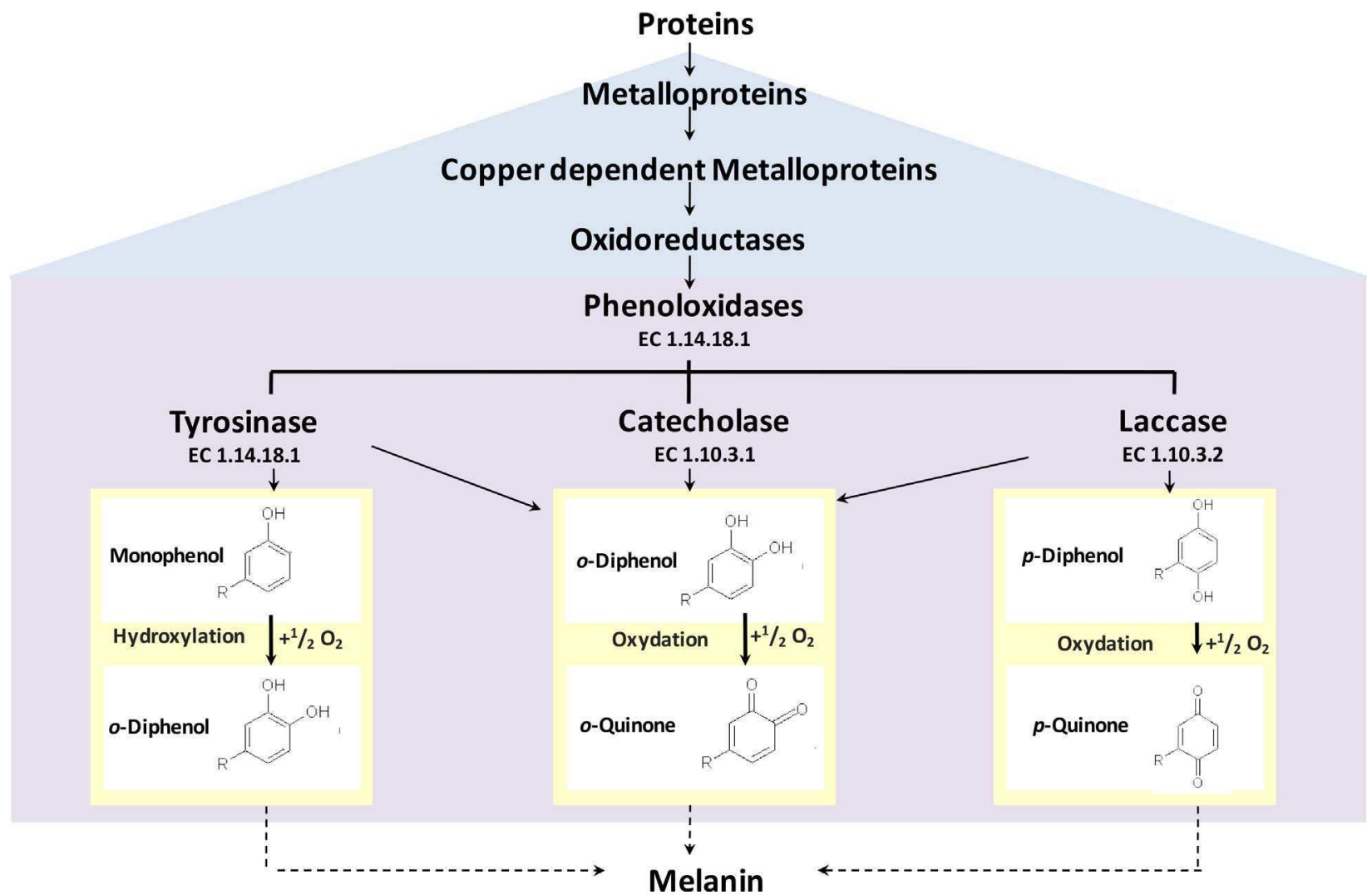

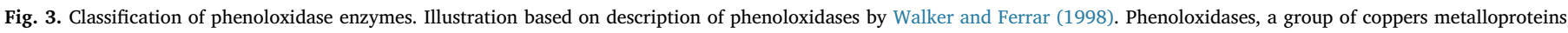

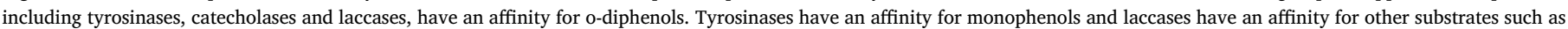
$\mathrm{m}$ - and p-diphenols or aromatic amines. 
Table 1

Phenoloxidases from bivalves: characteristics reported in the literature.

\begin{tabular}{|c|c|c|c|c|}
\hline Vernacular name & Scientific name & Molecular weight $(\mathrm{kDa})$ & Localization & Reference \\
\hline Ribbed mussel & Modiolus demissus & 70 & Periostracum & Waite and Wilbur (1976) \\
\hline \multirow[t]{2}{*}{ Blue mussel } & Mytilus edulis & 381,316 & HLS $^{\mathrm{a}}$ & Renwrantz et al. (1996) \\
\hline & & $49,135,260$ & Foot gland & Maruyama et al. (1991) \\
\hline Manila clam & Ruditapes philippinarum & 76.9 & Haemolymph & Cong et al. (2005) \\
\hline Eastern oyster & Crassostrea virginica & 133 & $\mathrm{HMS}^{\mathrm{b}}$ & Jordan and Deaton (2005) \\
\hline Japanese pearl oyster & Pinctada fucata & 43,49 & Prismatic shell layer & Nagai et al. (2007) \\
\hline \multirow[t]{3}{*}{ Pacific oyster } & Crassostrea gigas & $\sim 10, \sim 200$ & Gills, DG ${ }^{\mathrm{c}}$, Mantle & Luna-Acosta et al. (2011a, 2011b, 2011c) \\
\hline & & $\sim 40$ & Muscle & \\
\hline & & $\sim 10$ & Plasma, HLS ${ }^{\mathrm{a}}$ & \\
\hline
\end{tabular}

${ }^{\text {a }}$ HLS: haemocyte lysate supernatant.

b HMS: haemocyte membrane supernatant.

${ }^{\mathrm{c}}$ DG: digestive gland.

2011c), mantle (Jaenicke and Decker, 2003; Liang et al., 2007; LunaAcosta et al., 2011c) and shell (Nagai et al., 2007; Huan et al., 2013).

Most studies in bivalves have been done in haemolymphatic compartments (e.g. Asokan et al., 1997; Pipe et al., 1999; Luna-Gonzalez et al., 2003; Gagnaire et al., 2004; Bouilly et al., 2006; Thiagarajan et al., 2006; Luna-Acosta et al., 2010b; Chakraborty et al., 2013). However, in bivalves, POs appear to play different roles depending on the tissue (Table 2).

\section{Activation mechanism}

In invertebrates, the infection by a pathogen agent can lead to an immune response. This response includes the activation of proteins constitutively present in the haemolymph such as PO, which exists as an inactive zymogene called prophenoloxidase (proPO; Cerenius et al., 2008). In bivalves, although no studies have sought to elucidate the activation mechanisms of the proPO system in vivo, to our knowledge, some studies have been carried out on the modulation of the PO activity or the expression of the gene coding for a PO in relation to exposure to pathogens: using activating agents, such as: 1 ) pathogen agents (Perkinsus marinus, $P$. atlanticus, Alexandrium minutum, Ostreid herpesvirus 1); 2) exogenous proteases, such as trypsin and chymotrypsin; 3) pathogenassociated molecular patterns (PAMPs, such as lipopolysaccharides -LPS- or zymosan); 4) detergents, such as Triton X-100 and sodium dodecyl sulphate (SDS); 5) or other environmental stressors, such as exposure to air, high-pressure water jets, hypo-saline conditions or mechanical agitation (e.g. Jordan and Deaton, 2005; Muñoz et al., 2006; Aladaileh et al., 2007; Haberkorn et al., 2010; Kuchel et al., 2010; Renault et al., 2011; Raftos et al., 2014).

\section{Phenoloxidase substrates and inhibitors}

Most studies on POs in bivalves have been carried out using common substrates of different POs, i.e. o-diphenols such as L-DOPA or dopamine (e.g. Asokan et al., 1997; Luna-Gonzalez et al., 2003;
Gagnaire et al., 2004; Bouilly et al., 2006; Thiagarajan et al., 2006; Jing et al., 2006; Hellio et al., 2007; Thomas-Guyon et al., 2009; Cong et al., 2013).

However, contrary to vertebrates that possess only tyrosinases, the three types of POs have been detected in several invertebrates, e.g. tyrosinase in the vinegar fly Drosophila melanogaster (Asada et al., 1993), catecholase in the crab Charybdis japonica (Liu et al., 2006), catecholase and laccase in the crayfish Procambarus clarkii (Cardenas and Dankert, 2000), cresolase and laccase activities in the Manila clam Venerupis philippinarum (Schosinsky et al., 1974), cresolase activity in the clam $R$. philippinarum (Cong et al., 2005), catecholase activity in the oyster C. virginica (Jordan and Deaton, 2005), and catecholase and laccase activities in the Pacific oyster $C$. gigas (Luna-Acosta et al., 2010b; Luna-Acosta et al., 2011c). Because of their low specificity, common substrates of the three types of POs (tyrosinases, catecholases and laccases) are not appropriate to distinguish the three types of PO activity (cresolase, catecholase and laccase). The three types of PO activity can be identified by using more specific substrates, such as monophenols, to detect cresolase activities. To detect laccase activities, p-diphenols, m-diphenols or non-phenolic substrates can be used.

Many difficulties arise when PO activities are identified in crude or in partially purified tissue homogenates because PO substrates can be used by other proteins, such as ceruloplasmins (or ferroxidases), haemocyanins, cytochrome oxidases and/or peroxidases. However, among these proteins, ceruloplasmins or ferroxidases (EC 1.16.3.1) have only been detected, to our knowledge, in invertebrates (Le Bris et al., 2013). In addition, in most lamellibranch mollusc, such as oysters, haemocyanines are not present (Kennedy et al., 1996). Moreover, the presence of cytochrome oxidases (EC 1.9.3.1) can be excluded by working with soluble preparations, because cytochrome oxidases are transmembrane proteins that remain associated with membrane fragments (Smith and Stotz, 1954). Finally, contrary to oxidation reactions catalyzed by POs, which require the presence of $\mathrm{O}_{2}$, reactions catalyzed by peroxidases (EC 1.11.1.7) require the presence of hydrogen peroxide $\left(\mathrm{H}_{2} \mathrm{O}_{2}\right)$. Therefore, the oxygen consumption during the enzyme reaction can be

Table 2

Localisation and roles of PO in different tissues in bivalves.

\begin{tabular}{|c|c|c|}
\hline Tissue & Role & References \\
\hline $\begin{array}{l}\text { Haemocytes and } \\
\text { plasma }\end{array}$ & Immune effectors cells and plasmatic mediators. & $\begin{array}{l}\text { Thomas-Guyon et al. (2009), Luna-Acosta et al. (2011a), } \\
\text { Raftos et al. (2014), Matozzo and Bailo (2015) }\end{array}$ \\
\hline Gill & $\begin{array}{l}\text { Dopamine is a potential inhibitor of cilio-excitatory fibers in gills. In gills, dopamine is } \\
\text { transformed by reactions catalyzed by POs, leading to the formation of melanin. }\end{array}$ & Malanga and Young (1978) \\
\hline Digestive gland & $\begin{array}{l}\text { Phenoloxidases are present in a zone of the digestive gland called the cristallin style in the } \\
\text { lamellibranchs. Its role is unknown. }\end{array}$ & Bailey and Worboys (1960) \\
\hline Mantle and shell & Production and repair of the shell. & $\begin{array}{l}\text { Liang et al. (2007), Marie et al. (2012), Huan et al. } \\
\text { (2013) }\end{array}$ \\
\hline Foot & $\begin{array}{l}\text { Bivalves that have a foot can attach themselves to substrates thanks to tanned proteins } \\
\text { secreted by a series of glands associated to the foot. POs present in these glands are } \\
\text { implicated in the production of tanned proteins. }\end{array}$ & Bharathi and Ramalingam (1983) \\
\hline
\end{tabular}


Table 3

Mode of action of phenoloxidase inhibitors in several species.

\begin{tabular}{ll}
\hline Type of inhibition & Category of compounds and mode of action \\
\hline Inhibitors acting on the enzyme & Reducing agents: \\
& Sulphites can bind to sulfhydryl groups of the \\
active site of the enzyme but can also interact \\
with quinones forming sulfoquinones. \\
- Antioxidants inhibit oxidative processes by \\
reacting with free radicals, via a metallic \\
chelation and a fixation of oxygen. \\
Chelators:
\end{tabular}

- Metal chelators have two electrons that interact with copper or iron ions.

- Compounds with a similar structure to phenols are more efficient than metal chelators. In both cases, this inhibition takes place in an acid reaction medium.

- Polysaccharides can also interact with copper ions.

Acidifying agents: they can inhibit the enzyme (at $\mathrm{pH}$ 3-4) and even increase the efficiency of inhibitors such as sodium chloride $(\mathrm{NaCl})$ or calcium chloride $\left(\mathrm{CaCl}_{2}\right)$ that inhibit POs but only in the presence of ascorbic acid.

Inhibitors acting on the active site of the enzyme or that fix on the substrates (competitive inhibitors)

Inhibitors acting in other sites (non-competitive inhibitors)

Inhibitors acting on PO substrate (phenol absorbing agents)

Inhibitors acting on oxidation products (quinones)

Inhibitors acting on the enzymes (tyrosinase, catecholase, laccase)

Some acids have structural similarities with POs but are "difficultly oxydable".

Halide salts: inhibition occurs generally in acidic reaction media.

Amino acids, peptides and proteins: direct inhibition of the enzyme, through chelation of copper ions or reaction with quinones. Histidines and cysteines have a strong affinity for $\mathrm{Cu}^{2+}$, via their imidazole or thiol group. Thiol groups form sulphide adducts with o-quinones that inhibit the formation of polymers.

Aldehydes: they attack aldehyd groups present in the lateral chain of POs, leading to the formation of stable Schiff bases.

These inhibitors have limited efficiency. They form complexes with phenols. $\beta$-(1,4)-D-glucosamine polymers are by-products of the chitin deacetylation in shells: these polymers inhibit reaction where POs are involved, forming a barrier that prevents interactions with oxygen. They link to phenolic compounds but also to copper atoms of the $\mathrm{PO}$ active site. Sulphate groups can bind to phenols or be copper ion chelators.

They reduce quinones and generate parental phenols (antioxidant and antiradical action) in the presence of citric acid, sodium metabisulfite, EDTA and chloride ions, but their effect is temporary since they oxidize quinines. Cysteine contains a sulphurated amino acid that traps o-quinones as stable and uncolored products.

a Tyrosinase inhibitor,

b Catecholase inhibitor,

c Laccase inhibitor

Cuminaldehyde, anisaldehyde, 2-hydroxi-4-

methoxibenzaldehyde (HMB), (2E)-alkenals

Active carbon and bentonite, $\alpha, \beta$, or $\gamma$-cyclodextrine, carraghenanes, xylane or amylose sulphates, algae extracts

Sulphite $\left(\mathrm{SO}_{3}{ }^{2-}\right)$, butilated hydroxianisole (BHA), tertiarybutyl hydroxiquinone (TBHQ), propyl gallate (PG), 2-mercaptoethanol (2-ME), sodium azide $\left(\mathrm{NaN}_{3}\right)$, carbon monoxide (CO), ethylenediamine tetra-acetic acid (EDTA), metallothioneines (MT), diethyldithiocarbamate (DETC), phosphatases (ATP and pyrophosphates), macromolecules (porphyrines, proteins), tropolone, mimosine, sulphate, pectine, hydrogen peroxide $\left(\mathrm{H}_{2} \mathrm{O}_{2}\right)$, dithiothreitol (DTT), phenylhydrazine, ferrocyanure, glutathione, hydroxylamine $\left(\mathrm{NH}_{2} \mathrm{OH}\right)$, acids (ascorbic, citric, malic, gallic, oxalic, succinic, kojic).

Sodium bromide (NaBr), L-lysine, L-glycine, L-histidine and

(4-HR), kojic acid and tropolone are metal chelators but also competitive inhibitors of POs.

Acids, cysteine, arbutine, hinokitiol, barbarine, flavonol derivates, resveratrol, $o$-methyl-transferases, oxigenases, quinone isomerases and quinone methide reductase, papaine

- DETC (diethyldithiocarbamate) ${ }^{\mathrm{a}, \mathrm{b}, \mathrm{c}}$ Copper chelation (competitive inhibition)

- PTU (1-phenyl 2-thiourea) ${ }^{\text {a,b,c }}$ Copper chelation (competitive inhibition): sulphur binds to copper at the active site of the enzyme, blocking accessibility of the substrate.

- Tropolone ${ }^{\mathrm{a}, \mathrm{b}, \mathrm{c}}$ Substrate of peroxidases and inhibitor of POs (copper chelation).

- 2-ME (2-mercaptoethanol) ${ }^{\mathrm{a}, \mathrm{b}, \mathrm{c}}$ Reducing agent: sulphurcontaining compounds are quinone chelators, blocking their participation in secondary reactions of melanization and/or acting directly with the enzyme.

- NaN3 (sodium azide) ${ }^{\mathrm{a}, \mathrm{b}, \mathrm{c}}$ Metal chelator: inhibitor of all types of POs.

- 4-HR (4-hexylresorcinol) ${ }^{\mathrm{a}, \mathrm{b}}$ Fixation on the active site: competitive inhibitor of tyrosinases and catecholases but not of laccases.

- SHAM (salicylhydroxamic acid) ${ }^{\mathrm{a}, \mathrm{b}}$ Metal chelator described as an inhibitor of alternative oxidases in plants: competitive inhibitor of tyrosinases and catecholases but not of laccases. Kojic acid ${ }^{\mathrm{a}, \mathrm{b}, \mathrm{c}}$ competitive or mixed-type inhibitor of POs CTAB (cetyltrimethylammonium bromide) ${ }^{\mathrm{c}}$ Cationic detergent:
References

Dawley and Flurkey (1993)

Dawley and Flurkey (1993)

Jimenez et al. (2001)

Simpson et al (1997), Hellio et al. (2000)

Zhao et al. (2005)

Luna-Acosta et al. (2010a, 2010b) 


\begin{tabular}{|c|c|c|c|}
\hline Type of inhibition & Category of compounds and mode of action & Examples & References \\
\hline & & $\begin{array}{l}\text { competitive or non-competitive inhibitor of laccases, but not of } \\
\text { other POs }\end{array}$ & \\
\hline
\end{tabular}

measured by oxymetry. This approach makes it possible to confirm whether oxygen is consumed when measuring PO activity (Luna-Acosta et al., 2010b). In addition, spectrophotometric studies using catalase, which catalyzes the transformation of $\mathrm{H}_{2} \mathrm{O}_{2}$ into $\mathrm{O}_{2}$ and $\mathrm{H}_{2} \mathrm{O}$, enables confirmation of whether the activity measured is of peroxidasic origin (Luna-Acosta et al., 2010b).

POs can also be differentiated by the specificity of some inhibitors for these enzymes. The difference of action of some inhibitors on tyrosinases, catecholases and laccases would probably be due to differences in mechanical reactions and levels of oxidation of copper at the active sites of these three types of enzymes.

However, particular attention must be paid when choosing inhibitors. Indeed, several compounds described in the literature as specific PO inhibitors can have a non-specific inhibitory effect, i.e. not acting directly on the enzyme (Table 3 ). For example, molecules such as 2-mercaptoethanol (2-ME) are described as specific PO inhibitors (see Luna-Acosta et al., 2010b for references). However, because of their reducing agent characteristics, 2-ME can inhibit autooxidation and enzyme oxidation reactions by interacting with the substrate and/or the quinones produced following these two types of reaction, and therefore cannot exert a direct inhibitory effect on the enzyme (Table 3). Consequently, reducing agents should not be considered as specific PO inhibitors. Recently, among several inhibitors that were tested (DETC, PTU, tropolone, 2-ME, NaN3, 4-HR, SHAM, CTAB) only PTU, tropolone, 4-HR, SHAM and CTAB were demonstrated to be specific PO inhibitors (Luna-Acosta et al., 2010b).

\section{Methods of evaluation of PO activity}

One of the main constraints when working with POs is that almost every study is carried out with a different technique, which renders comparison between different studies difficult.

One of the first techniques developed to study POs in bivalves was cell staining (Hellio et al., 2000). Although this technique allows cell location, it does not provide precise information on the activity of the enzyme. Additionally, even if the histochemical approach to study POs and to evaluate the amount of melanin granules in the cells is an important data, the presence of lipofuscin lysosomal accumulation may interfere in the assay, especially in the digestive gland of molluscs, in which the lysosomal lipofuscin accumulation is usually considered as a biomarker of oxidative stress (Pearse, 1985). More recently, the realtime PCR technique (RT PCR) has been used to study the effect of contaminants on gene expression, e.g. Bado-Nilles et al. (2010), LunaAcosta et al. (2012). The homology of different probes used to quantify the mRNA in the different organisms is useful for this type of technique (Pfaff, 2001; Timothy et al., 2016). However, in addition to the fact that molecular approaches are more expensive than cellular ones, studies on the scale of the gene only furnish information on regulations that may occur at the transcriptional level, omitting regulations that can occur at post-transcriptional and/or post-traductional levels.

In comparison with other techniques, measuring activities by spectrophotometry is relatively easy to carry out. It is also cheap and enables quantitative information to be obtained on the activity of the enzymes. Therefore, most studies on the effect of contaminants on PO activities in bivalves have been carried out via spectrophotometrical measurement of the appearance of a product or the disappearance of the substrate in the reaction catalyzed by the enzyme (e.g. Hellio et al., 2000; Gagnaire et al., 2004; Jing et al., 2006; Thiagarajan et al., 2006; Bado-Nilles et al., 2009a, 2009b; Luna-Acosta et al., 2010a; Luna-
Acosta et al., 2010b; Buffet et al., 2013; Cong et al., 2013; Buffet et al., 2014; Haberkorn et al., 2014; Mouneyrac et al., 2014; Milinkovitch et al., 2015a, 2015b; Breitwieser et al., 2016). Two types of spectrophotometrical analyses can be performed: endpoint analysis or kinetic analysis. However, concerning the endpoint analysis, the quantity of the product formed at time $\mathrm{t}$ (discontinuous assay) does not always reflect the real concentration of the enzyme. It may be the case that at a high enzyme concentration, the reaction occurs in its totality or attains the equilibrium during the time used for the assay. In that case, adding supplementary enzyme would not increase the formation of product, leading consequently, to a potential under-estimation of the enzyme activity (Pelmont, 1995). Conversely, when kinetic analysis is performed through a continuous assay, at initial velocity of the reaction, the number of molecules of the product formed (or the disappeared substrate) as a function of time, will be proportional to the enzyme concentration, giving more accurate information. In addition, the oxidation catalyzed by POs needs the presence of $\mathrm{O}_{2}$ and PO substrates are rapidly autooxidized, i.e. oxidized in the absence of the enzyme, in contact with air. This autooxidation leads, in the same way as in the presence of POs, to the formation of quinones. Therefore, it is important to perform a controlled kinetic analysis in the absence of enzymes and in the presence of the only substrate of the reaction. Autooxidation values obtained may be taken into consideration to calculate the final enzyme activity of the sample.

\section{Potential roles of PO in bivalve invertebrates}

POs appear to play different roles depending on the tissue, such as immune effectors in haemocytes, mediators in plasma, or as molecules implicated in the formation of tanned proteins in gills, foot and mantle or in the production and repair of the shell, from what is known so far (Table 2). Additionally, POs have also attracted attention during the last decade for their potential to be used as biomarkers in bivalves exposed to contaminants. Indeed, different authors have shown that PO activities in bivalves can be modulated by inorganic (Table 5) (Gagnaire et al., 2004; Jing et al., 2006; Chakraborty et al., 2010; Buffet et al., 2013; Chakraborty et al., 2013; Cong et al., 2013; Buffet et al., 2014; Haberkorn et al., 2014; Mouneyrac et al., 2014; Milinkovitch et al., 2015a, 2015b; Breitwieser et al., 2016) and organic contaminants (Table 6) (Gagnaire et al., 2004; Bado-Nilles et al., 2009a, 2009b; BadoNilles et al., 2010; Luna-Acosta et al., 2011b; Luna-Acosta et al., 2012; Bianchi et al., 2014; Díaz-Resendiz et al., 2014; Milinkovitch et al., 2015b; Breitwieser et al., 2016) (Table 3).

Moreover, in situ transplantation studies were carried out with multiple biomarkers, including laccase in C. gigas (Luna-Acosta et al., 2015a, 2015b) and the biological effects of chemical pollution in a harbour were studied to develop a multi-biomarker approach on marine species and to consider the environmental variability (climatic and anthropic) (Laitano and Fernández-Gimenez, 2016; Breitwieser et al., 2017). On the basis of the principal results obtained in these studies, we hypothesize that, when a contaminant enters an organism, POs are likely to play different roles in bivalves (Fig. 1).

Firstly, the participation of POs in defenses and in non-self recognition of foreign biological agents in invertebrates (Cerenius et al., 2008), and the suspected involvement in resistance to infections by pathogens in bivalves (e.g. (Jordan and Deaton, 2005; Muñoz et al., 2006; Aladaileh et al., 2007; Haberkorn et al., 2010; Kuchel et al., 2010; Renault et al., 2011; Raftos et al., 2014; Le Bris et al., 2015; Richard et al., 2015), suggest that POs play a crucial immune role when foreign 
Table 4

Bivalve studies on the modulation of PO activity in relation to experiments of exposure to pathogen agents or toxins.

\begin{tabular}{|c|c|c|c|c|c|c|c|}
\hline Organism & Parameter & Experiment & Approach & Time & Tissue compartment & Results & Reference \\
\hline $\begin{array}{l}\text { Australian cupped oyster } \\
\text { Saccostrea glomerata }\end{array}$ & $\begin{array}{l}\text { Infection by the protozoan } \\
\text { parasite Marteilia syneyi }\end{array}$ & $\begin{array}{l}\text { Comparison between oysters from a zone } \\
\text { affected by the QX disease and an unaffected } \\
\text { zone }\end{array}$ & In vivo & NI & Haemolymph & $\begin{array}{l}\text { Significant negative correlation between PO activity } \\
\text { and the infection: } \downarrow \text { of PO activity PO with } \uparrow \text { of infection }\end{array}$ & $\begin{array}{l}\text { Peters and Raftos } \\
\text { (2003) }\end{array}$ \\
\hline $\begin{array}{l}\text { American oyster Crassostrea } \\
\quad \text { virginica and ribbed mussel } \\
\quad \text { Geukensia demissa }\end{array}$ & $\begin{array}{l}\text { Infection by the protozoan } \\
\text { parasite Perkinsus marinus }\end{array}$ & $\begin{array}{l}\text { Samples of haemolymph incubated with cells } \\
\text { of Perkinsus marinus }\end{array}$ & In vitro & $6 \mathrm{~h}$ & Hc membrane & $\begin{array}{l}\text { At } 2 \mathrm{~h}: \uparrow \text { of PO activity in both species } \\
\text { At } 6 \mathrm{~h} \text { : new } \uparrow \text { of PO activity in both species } \\
\text { The transitory inhibition of PO activity in the host } \\
\text { could play a role in the infection by Perkinsus marinus }\end{array}$ & $\begin{array}{l}\text { Jordan and Deaton } \\
(2005)\end{array}$ \\
\hline $\begin{array}{l}\text { Common clam Venerupis } \\
\text { decussata }\end{array}$ & $\begin{array}{l}\text { Infection by the protozoan } \\
\text { parasite Perkinsus } \\
\text { atlanticus }\end{array}$ & $\begin{array}{l}\text { Comparison between clams from different } \\
\text { sites with different levels of infestation }\end{array}$ & In vivo & NI & $\begin{array}{l}\mathrm{Hc} \\
\mathrm{Hc}\end{array}$ & $\begin{array}{l}\uparrow \times 5 \text { of PO activity following a mild infestation } \\
\uparrow \times 5 \text { of PO activity following a low infestation }\end{array}$ & Muñoz et al. (2006) \\
\hline Pacific oyster Crassostrea gigas & $\begin{array}{l}\text { Exposure to the } \\
\text { dinoflagellate Alexandrium } \\
\text { minutum }\end{array}$ & $\begin{array}{l}\text { Exposure to Alexandrium minutum (Isochrysis } \\
\text { sp. or clone Tahitian T Iso has been used as a } \\
\text { non-toxic control) }\end{array}$ & In vivo & 4 days & Hс & $\begin{array}{l}\downarrow 75 \text { and } 50 \% \text { of PO activity in diploid and triploid } \\
\text { oysters exposed to } A \text {. minutum in comparison to control, } \\
\text { at an early stage of gonadal maturation (April), } \\
\text { respectively. } \\
\downarrow 30 \% \text { and } \uparrow \times 1.5 \text {-fold of PO activity in diploid and } \\
\text { triploid oysters exposed to } A \text {. minutum in comparison to } \\
\text { control, at an advanced stage of gonadal maturation } \\
\text { (April), respectively. }\end{array}$ & $\begin{array}{l}\text { Haberkorn et al. } \\
\text { (2010) }\end{array}$ \\
\hline Pacific oyster Crassostrea gigas & $\begin{array}{l}\text { Infection by Ostrea herpes } \\
\text { virus (OsHV-1) }\end{array}$ & $\begin{array}{l}\text { Suppressive substractive hybrization (SSH) } \\
\text { following an infection of oysters by OsHV-1 }\end{array}$ & In vivo & NI & $\mathrm{Hc}$ & Over expression of a gene coding for a laccase & Renault et al. (2011) \\
\hline Pacific oyster Crassostrea gigas & $\begin{array}{l}\text { Incubation with Vibrio } \\
\text { splendidus and Vibrio } \\
\text { aestuarianus }\end{array}$ & $\begin{array}{l}\text { Vibrio sp. incubation with } C \text {. gigas plasma to } \\
\text { detect effects of catecholase-type PO activity } \\
\text { and laccase-type PO activity }\end{array}$ & In vivo & $7 \mathrm{~h}$ & $\begin{array}{l}\text { Digestive gland, gills, } \\
\text { mantle, haemolymph }\end{array}$ & $\begin{array}{l}\text { Results suggest for the first time that antibacterial } \\
\text { activities from } C \text {. gigas potentially involve POs, and } \\
\text { more particularly laccase catalyzed reactions. }\end{array}$ & $\begin{array}{l}\text { Luna-Acosta et al. } \\
\text { (2011a, 2011b, } \\
\text { 2011c) }\end{array}$ \\
\hline $\begin{array}{l}\text { Manila clam Venerupis } \\
\text { philippunarium }\end{array}$ & Infection by Vibrio tapetis & $\begin{array}{l}\text { Extrapallial injection with } V \text {. tapetis on } \\
\text { phenoloxidase activity }\end{array}$ & In vivo & 30 days & Mantle & $\begin{array}{l}\text { Clam's immunity could be enhanced at } 22^{\circ} \mathrm{C} \text { while } V \text {. } \\
\text { tapetis virulence is lowered at this temperature. } \\
\text { Another result was the increase of PO and SOD basal } \\
\text { activities as clams were exposed to warmer } \\
\text { temperature. }\end{array}$ & Richard et al. (2015) \\
\hline $\begin{array}{l}\text { Manila clam Venerupis } \\
\text { philippunarium }\end{array}$ & Infection by Vibrio tapetis & $\begin{array}{l}\text { Bacterial infection in the V. philippinarum } \\
\text { resulted in modulation of PO and SOD } \\
\text { activities that was both tissue- and time- } \\
\text { dependent. }\end{array}$ & In vivo & 30 days & Haemolymph & $\begin{array}{l}\text { Injections also impacted PO and SOD activities in both } \\
\text { tissues and confirmed a difference in pathogenicity } \\
\text { between the two } V \text {. tapetis strains. }\end{array}$ & Le Bris et al. (2015) \\
\hline
\end{tabular}

NI: not indicated; $\downarrow$ : decrease; $\uparrow:$ increase, Hc: haemocytes. 
Table 5

Effect of metals on constitutive PO activity in bivalves.

\begin{tabular}{|c|c|c|c|c|c|c|c|c|}
\hline Organism & Contaminant & Concentration & Approach & Time (days) & Method & Tissue & $\begin{array}{l}\text { Results on PO } \\
\text { activity }\end{array}$ & References \\
\hline $\begin{array}{l}\text { Blue mussel Mytilus } \\
\quad \text { edulis }\end{array}$ & $\mathrm{Cu}$ & $0.02 / 0.05 \mathrm{mg} . \mathrm{L}^{-1}$ & In vivo & 7 & $\begin{array}{l}\text { Blades } \\
\text { incubated } \\
\text { with L-DOPA }\end{array}$ & HL (Hc) & ns & Pipe et al. (1999) \\
\hline \multirow[t]{2}{*}{$\begin{array}{l}\text { Pacific oyster } \\
\quad \text { Crassostrea gigas }\end{array}$} & $\mathrm{Hg}$ & $2.10^{-6} / 2.10^{-5} \mathrm{M}$ & In vitro & 1 & $\begin{array}{l}\text { L-DOPA, } \\
490 \mathrm{~nm}, 21 \mathrm{~h}\end{array}$ & \multirow[t]{2}{*}{ HL (P) } & $\downarrow 95 \% / \downarrow 95 \%$ & $\begin{array}{l}\text { Gagnaire et al. } \\
\text { (2004) }\end{array}$ \\
\hline & $\mathrm{Cd}$ & $500 \mathrm{ng} \cdot \mathrm{L}^{-1}$ & In vivo & 66 & (CAC buffer) & & $\begin{array}{l}\uparrow \times 8 \text { The activity in } \\
\text { the control organism } \\
\text { diminished over } \\
\text { time }\end{array}$ & Bouilly et al. (2006) \\
\hline \multirow[t]{2}{*}{$\begin{array}{l}\text { Asian green mussel } \\
\text { Perna viridis }\end{array}$} & $\mathrm{Cu}$ & $20 \mu \mathrm{g} . \mathrm{L}^{-1}$ & In vivo & 25 & $\begin{array}{l}\text { L-DOPA, } \\
5 \mathrm{~min}\end{array}$ & \multirow[t]{2}{*}{ HL (P) } & $\begin{array}{l}\text { Day 5: } \downarrow 50 \% \\
\text { Day 15: } \uparrow \times 8 \\
\text { Day 25: } \uparrow \times 6\end{array}$ & $\begin{array}{l}\text { Thiagarajan et al. } \\
(2006)\end{array}$ \\
\hline & $\mathrm{Hg}$ & $10 \mu \mathrm{g} \cdot \mathrm{L}^{-1}$ & In vivo & 25 & & & $\begin{array}{l}\text { Day 5: } \downarrow 30 \% \\
\text { Day 15: } \uparrow \times 18 \\
\text { Day 25: } \uparrow \times 10\end{array}$ & \\
\hline \multirow[t]{3}{*}{$\begin{array}{l}\text { Pearl oyster Pinctada } \\
\quad \text { fucata }\end{array}$} & $\mathrm{Cu}$ & $0.05 \mu \mathrm{M}$ & In vivo & 3 & $\begin{array}{l}\text { L-DOPA } \\
\text { (method of } \\
\text { Pang et al., } \\
2005 \text { ) }\end{array}$ & GD & $\begin{array}{l}\text { At } 12 \mathrm{~h}: \mathrm{ns} \\
\text { At } 24 \mathrm{~h}: \downarrow 40 \% \\
\text { At } 48 \mathrm{~h}: \uparrow \times 1,5 \\
\text { At } 72 \mathrm{~h}: \mathrm{ns} \\
\text { At } 24 \mathrm{~h}: \uparrow \times 5 \\
\text { At } 72 \mathrm{~h}: \downarrow 50 \%\end{array}$ & Jing et al. (2006) \\
\hline & $\mathrm{Cu}$ & $0.5 \mu \mathrm{M}$ & In vivo & 3 & & $\begin{array}{l}\text { B } \\
\text { GD }\end{array}$ & $\begin{array}{l}\text { At } 72 \mathrm{~h}: \downarrow 40 \text { to } 60 \% \\
\text { At } 72 \mathrm{~h}: \uparrow 10 \%\end{array}$ & \\
\hline & $\mathrm{Pb}$ & $0.5 \mu \mathrm{M}$ & In vivo & 3 & & M & $\begin{array}{l}\text { At } 24 \mathrm{~h}: \downarrow 60 \% \\
\text { At } 48 \mathrm{~h}: \mathrm{ns} \\
\text { At } 72 \mathrm{~h}: \downarrow 60 \%\end{array}$ & Jing et al. (2006) \\
\hline $\begin{array}{l}\text { Freshwater mussel } \\
\quad \text { Lamellidens } \\
\text { marginalis }\end{array}$ & As & $5 \mathrm{mg} \cdot \mathrm{L}^{-1}$ & In vivo & 30 & $\begin{array}{l}\text { L-DOPA, } \\
490 \mathrm{~nm} \text {, } \\
1 \text { min. (CAC } \\
\text { buffer) }\end{array}$ & B & $\begin{array}{l}\text { At } 48 \text { and } 72 \mathrm{~h}: \uparrow \\
\times 2 \\
\text { At } 96 \mathrm{~h}: \uparrow \times 4 \\
\text { At } 30 \text { days: } \downarrow 50 \%\end{array}$ & $\begin{array}{l}\text { Chakraborty et al. } \\
\text { (2010) }\end{array}$ \\
\hline $\begin{array}{l}\text { Clam Scrobicularia } \\
\text { plana }\end{array}$ & $\begin{array}{l}\mathrm{Ag} \text { and } \mathrm{CuO} \\
\text { nanoparticles }\end{array}$ & $10 \mu \mathrm{g} . \mathrm{L}^{-1}$ & $\begin{array}{l}\text { In vivo } \\
\text { (Experimental } \\
\text { Mesocosms) }\end{array}$ & 21 & $\begin{array}{l}\text { PPD, } 420 \mathrm{~nm} \text {, } \\
2 \mathrm{~h} \text { (Tris } \\
\text { buffer) }\end{array}$ & Soft tissues & $\begin{array}{l}\text { For } 2 \text { experimental } \\
\text { conditions: } \uparrow\end{array}$ & $\begin{array}{l}\text { Buffet et al. (2013); } \\
\text { Buffet et al. (2014); } \\
\text { Mouneyrac et al. } \\
\text { (2014) }\end{array}$ \\
\hline $\begin{array}{l}\text { Scallop } \\
\qquad \begin{array}{l}\text { Mimachlamys } \\
\text { varia }\end{array}\end{array}$ & $\begin{array}{l}14 \text { trace elements } \\
\text { ( } \mu \mathrm{g} / \mathrm{G} \text { of dry } \\
\text { weight) }\end{array}$ & $\begin{array}{l}\text { Cd: } 36 \pm 4 \\
\text { Pb: } 1.5 \pm 0.1 \\
\text { Cu: } 55 \pm 11 \\
\text { Ag: } 9 \pm 1 \\
\text { Zn: } 91 \pm 9\end{array}$ & $\begin{array}{l}\text { In situ Atlantic } \\
\text { coast, France }\end{array}$ & March & $\begin{array}{l}\text { PPD, } 420 \mathrm{~nm}, \\
2 \mathrm{~h} \text { (Tris } \\
\text { buffer) }\end{array}$ & $\begin{array}{l}\text { Digestive } \\
\text { gland }\end{array}$ & $\begin{array}{l}\text { For } 2 \text { impacted sites: } \\
\uparrow \times 1.5\end{array}$ & $\begin{array}{l}\text { Milinkovitch et al. } \\
\text { (2015a, 2015b) }\end{array}$ \\
\hline $\begin{array}{l}\text { Scallop } \\
\qquad \text { Mimachlamys } \\
\quad \text { varia }\end{array}$ & $\begin{array}{l}14 \text { trace elements } \\
\text { ( } \mu \mathrm{g} / \mathrm{G} \text { of dry } \\
\text { weight) }\end{array}$ & $\begin{array}{l}\text { Cd: } 50 \pm 5 \\
\mathrm{~Pb}: 7 \pm 1 \\
\mathrm{Cu}: 100 \pm 22 \\
\mathrm{Ag}: 10 \pm 2 \\
\mathrm{Zn:} 150 \pm 32\end{array}$ & $\begin{array}{l}\text { In situ Atlantic } \\
\text { coast, France }\end{array}$ & $\begin{array}{l}\text { Summer } \\
\text { and winter } \\
\text { seasons }\end{array}$ & $\begin{array}{l}\text { PPD, } 420 \mathrm{~nm} \text {, } \\
2 \mathrm{~h} \text { (Tris } \\
\text { buffer) }\end{array}$ & $\begin{array}{l}\text { Digestive } \\
\text { gland }\end{array}$ & $\begin{array}{l}\text { Winter season (for } 1 \\
\text { impacted site): } \uparrow \times 2 \\
\text { Summer season (for } \\
\text { impacted sites): no } \\
\text { modulation }\end{array}$ & $\begin{array}{l}\text { Breitwieser et al. } \\
(2016)\end{array}$ \\
\hline $\begin{array}{l}\text { Scallop } \\
\qquad \begin{array}{l}\text { Mimachlamys } \\
\text { varia }\end{array}\end{array}$ & $\begin{array}{l}14 \text { trace elements } \\
\text { ( } \mu \mathrm{g} / \mathrm{G} \text { of dry } \\
\text { weight) }\end{array}$ & $\begin{array}{l}\text { As: } 19.33 \pm 0.95 \\
\text { Cd: } 39.85 \pm 6.23 \\
\text { Cu: } 41 \pm 7 \\
\text { Fe: } 694 \pm 72 \\
\text { Mn: } 15.76 \pm 1.36 \\
\text { Ni: } 2.99 \pm 0.41 \\
\text { Pb: } 2.20 \pm 0.14 \\
\text { Se: } 10.58 \pm 0.38 \\
\text { Zn: } 114 \pm 23 \\
\text { Ag:10.52 } \pm 1.03\end{array}$ & $\begin{array}{l}\text { In situ semi-closed } \\
\text { area: harbour }\end{array}$ & $\begin{array}{l}\text { Winter } \\
\text { season } \\
\text { January }\end{array}$ & $\begin{array}{l}\text { PPD, } 420 \mathrm{~nm} \text {, } \\
2 \mathrm{~h} \text { (Tris } \\
\text { buffer) }\end{array}$ & $\begin{array}{l}\text { Digestive } \\
\text { gland }\end{array}$ & $\begin{array}{l}\text { For all impacted } \\
\text { sites: } \uparrow 30 \%\end{array}$ & $\begin{array}{l}\text { Breitwieser et al. } \\
\text { (2017) }\end{array}$ \\
\hline $\begin{array}{l}\text { Oyster Crassostrea } \\
\quad \text { gigas }\end{array}$ & $\begin{array}{l}14 \text { trace elements } \\
\text { ( } \mu \mathrm{g} / \mathrm{G} \text { of dry } \\
\text { weight) }\end{array}$ & $\begin{array}{l}\text { As: } 34.22 \pm 1.5 \\
\text { Cd: } 2.18 \pm 0.19 \\
\text { Cu: } 100 \pm 12 \\
\text { Fe: } 439.45 \pm 66 \\
\text { Mn: } 20.68 \pm 2.3 \\
\text { Se: } 6.31 \pm 0.38 \\
\text { Zn: } 1485 \pm 260 \\
\text { Ag: } 6.52 \pm 0.57\end{array}$ & $\begin{array}{l}\text { In situ Semi-closed } \\
\text { area: harbour }\end{array}$ & $\begin{array}{l}\text { Winter } \\
\text { season } \\
\text { January }\end{array}$ & $\begin{array}{l}\text { PPD, } 420 \mathrm{~nm} \text {, } \\
2 \mathrm{~h} \text { (Tris } \\
\text { buffer) }\end{array}$ & $\begin{array}{l}\text { Digestive } \\
\text { gland }\end{array}$ & $\begin{array}{l}\text { For } 1 \text { impacted sites: } \\
\downarrow 50 \%\end{array}$ & $\begin{array}{l}\text { Breitwieser et al. } \\
\text { (2017) }\end{array}$ \\
\hline $\begin{array}{l}\text { Blue mussel Mytilus } \\
\quad \text { edulis }\end{array}$ & $\begin{array}{l}14 \text { trace elements } \\
\text { ( } \mu \mathrm{g} / \mathrm{G} \text { of dry } \\
\text { weight) }\end{array}$ & $\begin{array}{l}\text { As: } 34.25 \pm 1.38 \\
\text { Cd: } 0.84 \pm 0.06 \\
\text { Cu: } 12.95 \pm 0.5 \\
\text { Fe: } 2089 \pm 205 \mathrm{Mn}: \\
51 \pm 4 \\
\text { Pb: } 4.44 \pm 0.36 \\
\text { Se: } 6.97 \pm 0.27 \\
\text { Zn: } 79 \pm 4 \\
\text { Ag: } 0.13 \pm 0.02\end{array}$ & $\begin{array}{l}\text { In situ semi-closed } \\
\text { area: harbour }\end{array}$ & $\begin{array}{l}\text { Winter } \\
\text { season } \\
\text { January }\end{array}$ & $\begin{array}{l}\text { PPD, } 420 \mathrm{~nm} \text {, } \\
2 \mathrm{~h} \text { (Tris } \\
\text { buffer) }\end{array}$ & $\begin{array}{l}\text { Digestive } \\
\text { gland }\end{array}$ & $\begin{array}{l}\text { For all impacted } \\
\text { sites: } \uparrow 50 \%\end{array}$ & $\begin{array}{l}\text { Breitwieser et al. } \\
\text { (2017) }\end{array}$ \\
\hline
\end{tabular}

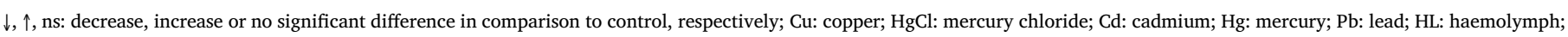
Hc: haemocytes; P: plasma; B: gills; GD: digestive gland; M: mantle. 
Table 6

Effect of biocides and hydrocrobons on constitutive PO activity in bivalves.

\begin{tabular}{|c|c|c|c|c|c|c|c|c|}
\hline Organism & Contaminant & Concentration & Approach & $\begin{array}{l}\text { Time } \\
\text { (days) }\end{array}$ & Method & Tissue & Results on PO activity & References \\
\hline \multicolumn{9}{|l|}{ Biocides } \\
\hline \multirow[t]{2}{*}{$\begin{array}{l}\text { Blue mussel Mytilus } \\
\quad \text { edulis }\end{array}$} & TBT & $10 \mathrm{mg} \cdot \mathrm{L}^{-1}$ & In vitro & NI & $\begin{array}{l}\text { Purified PO, L-DOPA, } \\
475 \mathrm{~nm}\end{array}$ & Foot & $\downarrow 76$ to $100 \%$ & Hellio et al. (2000) \\
\hline & $\mathrm{CuSO}_{4}$ & $10 \mathrm{mg} \cdot \mathrm{L}^{-1}$ & In vitro & NI & $\begin{array}{l}\text { Purified PO, L-DOPA, } \\
475 \mathrm{~nm}\end{array}$ & Foot & $\downarrow 76$ to $100 \%$ & \\
\hline \multicolumn{9}{|l|}{ Hydrocarbons } \\
\hline $\begin{array}{l}\text { Blue mussel Mytilus } \\
\text { edulis }\end{array}$ & Flt & $200 / 400 \mu \mathrm{g} . \mathrm{L}^{-1}$ & In vivo & 7 & $\begin{array}{l}\text { Blades incubated with L- } \\
\text { DOPA }\end{array}$ & $\mathrm{HL}(\mathrm{Hc})$ & $\uparrow \times 2 / \uparrow \times 4$ & $\begin{array}{l}\text { Coles and Pipe } \\
\text { (1994) }\end{array}$ \\
\hline \multirow[t]{4}{*}{$\begin{array}{l}\text { Pacific oyster } \\
\quad \text { Crassostrea gigas }\end{array}$} & $\mathrm{B}(\mathrm{b}) \mathrm{F}$ & $10^{-7} / 10^{-9} \mathrm{mg} \cdot \mathrm{L}^{-1}$ & In vitro & 1 & L-DOPA, 21 h, $490 \mathrm{~nm}$ & HL (P) & $\uparrow 40 \% / \uparrow 34 \%$ & $\begin{array}{l}\text { Bado-Nilles et al. } \\
\text { (2009a, 2009b) }\end{array}$ \\
\hline & HFO & $733 \pm 111 \mathrm{ng} \cdot \mathrm{L}^{-1}$ & In vivo & 9 & L-DOPA, 21 h, $490 \mathrm{~nm}$ & $\mathrm{HL}(\mathrm{P})$ & $\begin{array}{l}\text { Day } 9 \text { (of exposure): } \downarrow 10 \% \\
\text { Day } 3 \text { (of recovery): } \downarrow 20 \% \\
\text { Day14 (of recovery): } \downarrow 20 \% \\
\text { Day } 30 \text { (of recovery): ns }\end{array}$ & $\begin{array}{l}\text { Bado-Nilles et al. } \\
\text { (2009a, 2009b) }\end{array}$ \\
\hline & LCO & $600 \pm 315 \mathrm{ng} \cdot \mathrm{L}^{-1}$ & In vivo & 7 & L-DOPA, 21 h, $490 \mathrm{~nm}$ & HL (P) & $\begin{array}{l}\text { Day } 7 \text { (of exposure): } \downarrow 15 \% \\
\text { Day } 7 \text { (of recovery): } \downarrow 15 \% \\
\text { Day } 14 \text { (of recovery): } \downarrow \\
30 \%\end{array}$ & $\begin{array}{l}\text { Bado-Nilles et al. } \\
\text { (2010) }\end{array}$ \\
\hline & & & & & $\begin{array}{l}\text { qPCR (mRNA relative } \\
\text { expression of a gene } \\
\text { coding for a laccase) }\end{array}$ & $\mathrm{HL}(\mathrm{Hc})$ & Day 7 (de exposure): $\uparrow$ to 2 & \\
\hline $\begin{array}{l}\text { Pacific oyster } \\
\quad \text { Crassostrea gigas }\end{array}$ & $\begin{array}{l}\text { LPAHs } \\
\text { HPAHs } \\
\text { PCBs } \\
\text { PBDEs } \\
\text { DDTs } \\
\text { Lindane HCB + HC + TNC }\end{array}$ & $\begin{array}{l}63.37 \pm 14 \mu \mathrm{\mu g} \cdot \mathrm{Kg}^{-1} \mathrm{dw} \\
125 \pm 11 \mu \mathrm{gg} \cdot \mathrm{Kg}^{-1} \mathrm{dw} \\
51 \pm 10 \mu \mathrm{g} \cdot \mathrm{Kg}^{-1} \mathrm{dw} \\
1.07 \pm 0.35 \mu \mathrm{gg} \cdot \mathrm{Kg}^{-1} \mathrm{dw} \\
8.5 \pm 1.1 \mu \mathrm{gg} \cdot \mathrm{Kg}^{-1} \mathrm{dw} \\
1.1 \pm 0.3 \mu \mathrm{g} \cdot \mathrm{Kg}^{-1} \mathrm{dw} \\
2.42 \pm 0.67 \mu \mathrm{g} \cdot \mathrm{Kg}^{-1} \mathrm{dw}\end{array}$ & $\begin{array}{l}\text { In situ transplantation } \\
\text { sites }\end{array}$ & 90 & $\begin{array}{l}\text { Dopamine, } 4 \mathrm{~h}, 490 \mathrm{~nm} \\
\text { PPD, } 2 \mathrm{~h}, 420 \mathrm{~nm}\end{array}$ & Flesh & $\begin{array}{l}\text { PCB, PBDE and/or lindane } \\
\text { contamination: } \\
\text { Summer: } \\
\text { Gills: } \downarrow \text { for laccase-type PO } \\
\text { Digestive gland: } \downarrow \text { for } \\
\text { laccase-type PO } \\
\text { Mantle: } \downarrow \text { for laccase-type } \\
\text { PO } \\
\text { Plasma: } \downarrow \text { for laccase-type } \\
\text { PO }\end{array}$ & $\begin{array}{l}\text { Luna-Acosta et al. } \\
\text { (2015a, 2015b) }\end{array}$ \\
\hline & & & & & & & $\begin{array}{l}\text { Winter: } \\
\text { Gills: } \uparrow \text { for laccase-type PO } \\
\text { Digestive gland: } \downarrow \text { for } \\
\text { laccase-type PO } \\
\text { Mantle: } \uparrow \text { for laccase-type } \\
\text { PO } \\
\text { Plasma: } \downarrow \text { for laccase-type } \\
\text { PO }\end{array}$ & \\
\hline $\begin{array}{l}\text { Scallop Mimachlamys } \\
\quad \text { varia }\end{array}$ & $\begin{array}{l}\text { Pesticides } \\
\text { HAPs } \\
\text { PCBs }\end{array}$ & $\begin{array}{l}5 \pm 0.2 \mu \mathrm{g} \mathrm{Kg}^{-1} \mathrm{dw} \\
32 \pm 5 \mu \mathrm{Kg}^{-1} \mathrm{dw} \\
21.1 \pm 3 \mu \mathrm{Kg}^{-1} \mathrm{dw}\end{array}$ & In situ & NI & $\begin{array}{l}\text { Dopamine, } 4 \mathrm{~h}, 490 \mathrm{~nm} \\
\text { PPD, } 2 \mathrm{~h}, 420 \mathrm{~nm}\end{array}$ & $\begin{array}{l}\text { Digestive } \\
\text { glands }\end{array}$ & $\begin{array}{l}\text { Winter season (for three } \\
\text { impacted sites): } \downarrow \times 2 \\
\text { Summer season (for two } \\
\text { impacted sites): } \uparrow \times 1.5\end{array}$ & $\begin{array}{l}\text { Breitwieser et al. } \\
\text { (2016) }\end{array}$ \\
\hline $\begin{array}{l}\text { Pacific oyster } \\
\quad \text { Crassostrea gigas }\end{array}$ & $\begin{array}{l}\text { BAL } 110 \text { (Brut Arabian Light crude } \\
\text { oil topped at } 110^{\circ} \mathrm{C} \text { ) + FINASOL } \\
\text { (chemical dispersant) }\end{array}$ & $\begin{array}{l}67 \mathrm{mg} . \mathrm{L}^{-1} \text { BAL110 }+4 \mathrm{mg} \cdot \mathrm{L}^{-1} \text { of } \\
\text { chemical dispersant }\end{array}$ & In vivo & 2 & $\begin{array}{l}\text { Dopamine, } 4 \mathrm{~h}, 490 \mathrm{~nm} \\
\text { PPD, } 2 \mathrm{~h}, 420 \mathrm{~nm}\end{array}$ & HL (P) & $\begin{array}{l}2 \mathrm{~h} \text { (of exposure): } \mathrm{ns} \\
10 \mathrm{~h} \text { (of exposure): } \uparrow \times 2 \\
24 \mathrm{~h} \text { (of exposure): } \uparrow \times 3 \\
48 \mathrm{~h} \text { (of exposure): } \uparrow \times 2 \\
4 \text { weeks (of recovery): } \mathrm{ns}\end{array}$ & $\begin{array}{l}\text { Luna-Acosta et al. } \\
\text { (2017) }\end{array}$ \\
\hline
\end{tabular}

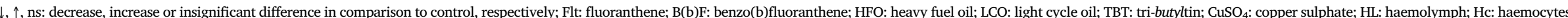

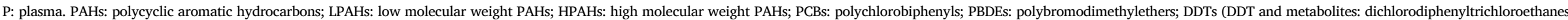

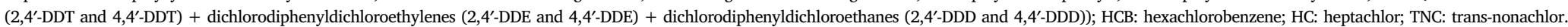


molecules enter the host (Table 4). Some other immune factors such as POs have also been discovered in the eggs or "embryos" and larvae stages of several molluscs (Bai et al., 1997; Thomas-Guyon et al., 2009). The existence of soluble immune mediators in eggs such as POs suggests compelling evidence that mollusc also practice transfer of innate immunity from parental material (mother) to offspring (Wang et al., 2015). In this case, POs could be considered as biomarkers of defense.

Secondly, when a contaminant enters an organism, it can be considerate as a certain type of stressor, enhancing a release of hormones and/or neurotransmitters, and especially catecholamines, or be considered as a non-self molecule (foreign biological agent), which can be recognized by pattern-recognition proteins (PRPs), or even be recognized as a xenobiotic (foreign chemical agent), leading to an activation of detoxification systems. In this review, we consider "stressor" as a challenging environmental condition, external stimulus, or event that disrupts homeostasis and generates a response of the organism, but that is not a chemical or a biological agent. In this case, foreign biological and chemical agents are separated from other types of stressors because the former induce some specific responses in the organism. The metabolization of contaminants by detoxification systems could lead to significant production of free radicals, consequently enhancing the activation of antioxidant enzymes, to maintain a homeostatic equilibrium in the organism. Therefore, POs, just like other antioxidant enzymes, could be used as biomarkers of contaminant exposure. The antioxidant properties of POs have been reported in the past in other living organisms (Lugasi, 1997) but no studies have been conducted to our knowledge in marine bivalves.

Thirdly, because of its affinity to different types of phenolic and non-phenolic substrates (Luna-Acosta et al., 2011b), POs could have an affinity for different organic contaminants, and, because of its oxidoreductive properties, could also play a role in the metabolization of contaminants (Luna-Acosta et al., 2011b). Thus, POs in bivalves could be involved in detoxification mechanisms of organic contaminants and could be used as biomarkers of defense (Table 6).

\section{Concluding remarks}

To conclude, with results published to date, one of the main difficulties concerning the enzymatic group of POs is that there exists a significant number of ambiguities and approximations in the literature. In the present review, we clarify that the term PO corresponds to a large group of enzymes and that there are three types of POs, which depend on substrate specificity: 1) tyrosinase EC 1.14.18.1, 2) catecholase EC 1.10.3.1 and 3) laccase EC 1.10.3.1. Because of their low specificity, common substrates or non-specific inhibitors of the three types of POs (tyrosinases, catecholases and laccases) are not appropriate to distinguish the three types of PO activity (cresolase, catecholase and laccase). In the present review, different specific substrates and inhibitors are suggested to identify the three types of PO activity. In addition, we recommend carrying out kinetic rather than endpoint analysis to more accurately assess PO activities in bivalve invertebrates.

Concerning its role, the presence of POs in the entire phylogenetic scale suggests that POs have important functions. Furthermore, recent studies in bivalves suggest that POs, and more particularly laccases, are likely to play a role in 1) immune defense 2) antioxidant and 3) detoxification mechanisms. Therefore, for a better understanding of the proPO system in bivalve invertebrates, it is necessary to further study PO roles and functions, and more particularly at the molecular and physiological levels of biological organization in order to propose them as biomarkers as a tool for the assessment of environmental health and management. Since POs can be considered as biomarkers of exposure (due to its antioxidant role) or defense (due to its immune and detoxification roles), it should be better to consider POs, and therefore laccases, as a key biomarker of environmental stress. In conclusion, this review provides evidence that POs could be used in multibiomarker approaches to detect early signs of impairment in natural bivalve populations, and suggests that monitoring of POs in the standardized procedures of the Water Frame Work Directive would allow the improvement of world water quality to be more accurately assessed.

\section{Acknowledgements}

This work was supported by grants from bodies such as the Communauté d'Agglomération de La Rochelle ( $\mathrm{PhD}$ for M. Breitwieser) and the Conseil Général de la Charente-Maritime ( $\mathrm{PhD}$ and mobility grants for A. Luna-Acosta). Also supported in part by the University of La Rochelle, Centre National de la Recherche Scientifique, Agence Nationale de la Recherche, Ifremer, FEDER, Conseil Régional PoitouCharentes (France).

\section{References}

Aladaileh, S., Nair, S.V., Raftos, D.A., 2007. Induction of phenoloxidase and other immunological activities in Sydney rock oysters challenged with microbial pathogenassociate molecular patterns. Fish Shellfish Immunol. 23, 1196-1208.

Amiard-Triquet, C., Amiard, J.C., Rainbow, P.S., 2006. Ecological Biomarkers. 464 CRC Press, Boca Ratón.

Asada, N., Fukumitsu, T., Fujimoto, K., Masuda, K., 1993. Activation of prophenoloxidase with 2-propanol and other organic compounds in Drosophila melanogaster. Insect Biochem. Mol. Biol. 23, 515-520.

Asokan, R., Arumugam, M., Mullainadhan, P., 1997. Activation of prophenoloxidase in the plasma and haemocytes of the marine mussel Perna viridis Linnaeus. Dev. Comp. Immunol. 21, 1-12.

Bado-Nilles, A., Quentel, C., Auffret, M., Le Floch, S., Gagnaire, B., Renault, T., ThomasGuyon, H., 2009a. Immune effects of HFO on European sea bass, Dicentrarchus labrax, and Pacific oyster, Crassostrea gigas. Ecotoxicol. Environ. Saf. 72, 1446-1454.

Bado-Nilles, A., Renault, T., Faury, N., Le Floch, S., Quentel, C., Auffret, M., ThomasGuyon, H., 2009b. In vivo effects of LCO soluble fraction on immune-related functions and gene transcription in the Pacific oyster, Crassostrea gigas (Thunberg). Aquat. Toxicol. 97, 196-203.

Bado-Nilles, A., Renault, T., Faury, N., Le Floch, S., Quentel, C., Auffret, M., ThomasGuyon, H., 2010. In vivo effects of LCO soluble fraction on immune-related functions and gene transcription in the Pacific oyster, Crassostrea gigas (Thunberg). Aquat. Toxicol. 97, 196-203.

Bai, G., Brown, J.F., Watson, C., Yoshino, T.P., 1997. Isolation and characterisation of phenoloxidase from egg masses of the gastropod mollusc, Biomphalaria glabrata. J. Comp. Biochem. Physiol. 118B, 463-469.

Bailey, K., Worboys, B., 1960. The lamellibranch crystalline style. Biochem. J. 76, 487-491.

Bharathi, N., Ramalingam, K., 1983. Electrophoretic study of the enzyme phenoloxidase from the enzyme gland in the foot of Perna viridis Linnaeus. J. Exp. Mar. Biol. Ecol. 70, $123-128$.

Bianchi, V.A., Castro, J.M., Rocchetta, I., Bieczynski, F., Luquet, C.M., 2014. Health status and bioremediation capacity of wild freshwater mussels (Diplodon chilensis) exposed to sewage water pollution in a glacial Patagonian lake. Fish Shellfish Immunol. 37, $268-277$.

Bouilly, K., Gagnaire, B., Bonnard, M., Thomas-Guyon, H., Renault, T., Miramand, P., Lapègue, S., 2006. Effects of cadmium on aneuploidy and hemocyte parameters in the Pacific oyster, Crassostrea gigas. Aquat. Toxicol. 78, 149-156.

Breitwieser, M., Viricel, A., Graber, M., Murillo, L., Becquet, V., Churlaud, C., Fruitier Arnaudin, I., Huet, V., Lacroix, C., Pante, E., Floch, S.L., Thomas-Guyon, H., 2016 Short-term and long-term biological effects of chronic chemical contamination on natural populations of a marine bivalve. PLoS ONE 11 (3) (art. no. e0150184).

Breitwieser, M., Viricel, A., Churlaud, C., Guillot, B., Martin, E., Stenger, P.L., Huet, V., Fontanaud, A., Thomas-Guyon, H., 2017. Evaluation of biological effects of diffuse contamination in a marina area on three bivalve marine species. Submitted in comp biochem and physiol - part C. Toxicology.

Buffet, P.E., Richard, M., Caupos, F., Vergnoux, A., Perrein-Ettajani, H., Luna-Acosta, A., Akcha, F., Amiard, J.C., Amiard-Triquet, C., Guibbolini, M., Risso-De-Faverney, C., Thomas-Guyon, H., Reip, P., Dybowska, A., Bernahu, D., Valsami-Jones, E., Mouneyrac, C.A., 2013. A mesocosm study of fate and effects of $\mathrm{CuO}$ nanoparticles on endobenthic species (Scrobicularia plana, Hediste diversicolor). Environ. Sci. Technol. 47, $1620-1628$

Buffet, P.E., Zalouk-Vergnoux, A., Châtel, A., Berthet, B., Métais, I., Perrein-Ettajani, H., Poirier, L., Luna-Acosta, A., Thomas-Guyon, H., Risso-de-Faverney, C., Guibbolini, M., Gilliland, D., Valsami-Jones, E., Mouneyrac, C., 2014. A marine mesocosm study on the environmental fate of silver nanoparticles and toxicity effects on two endobenthic species: the ragworm Hediste diversicolor and the bivalve mollusc Scrobicularia plana. Sci. Total Environ. 470-71, 1151-1159.

Cardenas, W., Dankert, J., 2000. Cresolase, catecholase and laccase activities in haemocytes of the red swamp crayfish. Fish Shellfish Immunol. 10, 33-46.

Cerenius, L., Lee, B.L., Söderhäll, K., 2008. The proPO-system: pros and cons for its role in invertebrate immunity. Trends Immunol. 29, 263-271.

Cerenius, L., Kawabata, S., Lee, B.-L., Nonaka, M., Söderhäll, K., 2010. Proteolytic cascades and their involvement in invertebrate immunity. Trends Biochem. Sci. 35, 575-583.

Chakraborty, S., Ray, M., Ray, S., 2010. Toxicity of sodium arsenite in the gill of an 
economically important mollusc of India. Fish Shellfish Immunol. 29, 136-148.

Chakraborty, S., Ray, M., Ray, S., 2013. Cell to organ: physiological, immunotoxic and oxidative stress responses of Lamellidens marginalis to inorganic arsenite. Ecotoxicol. Environ. Saf. 94, 153-163.

Claus, H., Decker, H., 2006. Bacterial tyrosinases. Syst. Appl. Microbiol. 29, 3-14.

Coles, J., Pipe, R., 1994. Phenoloxidase activity in the haemolymph and haemocytes of the marine mussel, Mytilus edulis. Fish Shellfish Immunol. 4, 337-352.

Cong, R., Sun, W., Liu, G., Fan, T., Meng, X., Yang, L., Zhu, L., 2005. Purification and characterisation of phenoloxidase from clam Ruditapes philippinarum. Fish Shellfish Immunol. 18, 61-70.

Cong, M., Lü, J., Wu, H., Zhao, J., 2013. Effect of cadmium on the defense response of Pacific oyster Crassostrea gigas to Listonella anguillarum challenge. Chin. J. Oceanol. Limnol. 31, 1002-1009.

Dawley, R., Flurkey, W., 1993. Differentiation of tyrosinase and laccase using 4-hexylresorcinol, a tyrosinase inhibitor. Phytochemistry 33, 281-284.

De Lafontaine, Y., Gagné, F., Blaise, C., Costan, C., Gagnon, P., Chan, H., 2000. Biomarkers in zebra mussels (Dreissena polymorpha) for the assessment and monitoring of water quality of the St Lawrence River (Canada). Aquat. Toxicol. 71, 50-51.

Decker, H., Terwillinger, N., 2000. Cops and robbers: putative evolution of copper oxygen-binding proteins. J. Exp. Biol. 203, 1777-1782.

Decker, H., Schweikardt, T., Nillius, D., Salzbrunn, U., Jaenicke, E., Tuczek, F., 2007. Similar enzyme activation and catalysis in hemocyanins and tyrosinases. Gene 398 183-191.

Díaz-Resendiz, K.J.G., Romero-Bañuelos, C.A., Robledo-Marenco, M.L., Rojas-García, A.E., Barrón-Vibanco, B.S., Medina-Díaz, I.M., Girón-Pérez, M.I., 2014. Deregulation of the humoral immune response of the oyster (Crassostrea corteziensis) exposed to naphthalene. Invertebr. Surviv. J. 11, 30-38.

Gagnaire, B., Thomas-Guyon, H., Renault, T., 2004. In vitro effects of cadmium and mercury on Pacific oyster, Crassostrea gigas (Thunberg), haemocytes. Fish Shellfish Immunol. 16, 501-512.

Gómez-Chiarri, M., Guo, X., Tanguy, A., He, Y., Proestou, D., 2015. The use of -omic tools in the study of disease processes in marine bivalve mollusks. J. Invertebr. Pathol. 131, 137-154.

Haberkorn, H., Lambert, C., Le Goïc, N., Guéquen, M., Moal, J., Palacios, E., Lassus, P., Soudant, P., 2010. Effects of Alexandrium minutum exposure upon physiological and hematological variables of diploid and triploid oysters, Crassostrea gigas. Aquat. Toxicol. 97, 96-108.

Haberkorn, H., Lambert, C., Le Goïc, N., Quéré, C., Bruneau, A., Riso, R., Auffret, M., Soudant, P., 2014. Cellular and biochemical responses of the oyster Crassostrea gigas to controlled exposures to metals and Alexandrium minutum. Aquat. Toxicol. 147, 158-167.

Hellio, C., Bourgougnon, N., Le Gal, Y., 2000. Phenoloxidase (E.C. 1.14.18.1) from Mytilus edulis byssus gland: purification, partial characterisation and application for screening products with potential antifouling activities. Biofouling 16, 235-244.

Hellio, C., Bado-Nilles, A., Gagnaire, B., Renault, T., Thomas-Guyon, H., 2007. Demonstration of a true phenoloxidase activity and activation of a proPO cascade in Pacific oyster, Crassostrea gigas (Thunberg) in vitro. Fish Shellfish Immunol. 22, 433-440.

Holloway, G., Sibly, R., Povey, S., 1990. Evolution of toxin-stressed environments. Funct. Ecol. 4, 289-294.

Huan, P., Liu, G., Wang, H., Liu, B., 2013. Identification of a tyrosinase gene potentially involved in early larval shell biogenesis of the Pacific oyster Crassostrea gigas. Dev. Genes Evol. 223, 389-394.

Jaenicke, E., Decker, H., 2003. Tyrosinases from crustaceans form hexamers. Biochem. J. $371,515-523$.

Jimenez, M., Chazarra, S., Escribano, J., Cabanes, J., García-Carmona, F., 2001. Competitive inhibition of mushroom tyrosinase by 4-substituted benzaldehydes. J. Agric. Food Chem. 49, 4060-4063.

Jing, G., Li, Y., Xie, L., Zhang, R., 2006. Metal accumulation and enzyme activities in gills and digestive gland of pearl oyster (Pinctada fucata) exposed to copper. Comp. Biochem. Physiol. 144C, 184-190.

Jordan, P., Deaton, L., 2005. Characterisation of phenoloxidase from Crassostrea virginica haemocytes and the effect of Perkinsus marinus on phenoloxidase activity in the hemolymph of Crassostrea virginica and Geukensia demissa. J. Shellfish Res. 24, 477-482.

Kan, H., Kim, C.H., Kwon, H.M., Park, J.W., Ron, K.B., Lee, H., 2008. Molecular control of penoloxidase-induced melanin synthesis in an insect. J. Biol. Chem. 283, 25316-25323.

Kennedy, V.S., Newell, R.I.E., Eble, A.F., 1996. The Eastern Oyster Crassostrea virginica. Maryland Sea Grant College, College Park (734 p).

Kuchel, R.P., Aladaileh, S., Birch, D., Vella, N., Raftos, D.A., 2010. Phagocytosis of the protozoan parasite, Marteilia sydneyi, by Sydney rock oyster (Saccostrea glomerata) hemocytes. J. Invertebr. Pathol. 1040, 97-104.

Laitano, M.V., Fernández-Gimenez, A.V., 2016. Are mussels always the best bioindicators? Comparative study on biochemical responses of three marine invertebrate species to chronic port pollution. Bull. Environ. Contam. Toxicol. 97, 50-55.

Le Bris, C., Paillard, C., Stiger-Pouvreau, V., Guérard, F., 2013. Laccase-like activity in the hemolymph of Venerupis philippinarum: characterization and kinetic properties. Fish Shellfish Immunol. 35 (1804:12).

Le Bris, C., Richard, G., Paillard, C., Lambert, C., Seguineau, C., Gauthier, O., Pernet, F., Guérard, F., 2015. Immune responses of phenoloxidase and superoxide dismutase in the manila clam Venerupis philippinarum challenged with Vibrio tapetis - part I: spatiotemporal evolution of enzymes' activities post-infection. Fish Shellfish Immunol. 42, $16-24$.

Liang, J., Wang, Y., Sun, H., 2007. The Electron Microscopic Cytochemistry Study of Peroxidase and Phenoloxidase in the Mantle of Chlamys farreri, Natural Science Edition. 1. Ludong University Daynalpp. 22-30.
Liu, G., Yang, L., Fan, T, Cong, R., Tang, Z, Sun, W, Xianghong, M., Liyan, Z, 2006. Purification and characterisation of phenoloxidase from crab Charybdis japonica. Fish Shellfish Immunol. 20, 47-57.

Lugasi, A., 1997. Natural Antioxidants: Chemistry, Health Effects and Application. AOCS Press, Urbana.

Luna-Acosta, A., Bustamante, P., Godefroy, J., Fruitier-Arnaudin, I., Thomas-Guyon, H., 2010a. Seasonal variation of pollution biomarkers to assess the impact on health status of juvenile Pacific oysters Crassostrea gigas exposed in situ. Environ. Sci. Pollut. Res. 17, 999-1008.

Luna-Acosta, A., Rosenfeld, E., Amari, M., Fruitier-Arnaudin, I., Bustamante, P., ThomasGuyon, H., 2010b. First evidence of laccase activity in the Pacific oyster Crassostrea gigas. Fish Shellfish Immunol. 28, 719-726.

Luna-Acosta, A., Saulnier, D., Pommier, M., Haffner, P., De Decker, S., Renault, T., Thomas-Guyon, H., 2011a. First evidence of a potential antibacterial activity involving a laccase-type enzyme of the phenoloxidase system in Pacific oyster Crassostred gigas haemocytes. Fish Shellfish Immunol. 31, 795-800.

Luna-Acosta, A., Kanan, R., Le Floch, S., Huet, V., Pineau, P., Bustamante, P., ThomasGuyon, H., 2011b. Enhanced immunological and detoxification responses in Pacific oysters, Crassostrea gigas, exposed to chemically dispersed oil. Water Res. 45, 4103-4118.

Luna-Acosta, A., Thomas-Guyon, H., Amari, M., Rosenfeld, E., Bustamante, P., FruitierArnaudin, I., 2011c. Differential tissue distribution and specificity of phenoloxidases from the Pacific oyster Crassostrea gigas. J. Comp. Biochem. Physiol. 159B, 220-226.

Luna-Acosta, A., Renault, T., Thomas-Guyon, H., Faury, N., Saulnier, D., Budzinski, H., Le Menach, K., Pardon, P., Fruitier-Arnaudin, I., Bustamante, P., 2012. Detection of early effects of a single herbicide (diuron) and a mix of herbicides and pharmaceuticals (diuron, isoproturon, ibuprofene) on immunological parameters of Pacific oyster, Crassostrea gigas, spat. Chemosphere 87, 1335-1340.

Luna-Acosta, A., Bustamante, P., Budzinski, H., Huet, V., Thomas-Guyon, H., 2015a. Persistent organic pollutants in a marine bivalve on the Marennes-Oléron Bay and the Gironde Estuary (French Atlantic Coast)—part 2: potential biological effects. Sci. Total Environ. 514, 511-522.

Luna-Acosta, A., Budzinski, H., Le Menach, K., Thomas-Guyon, H., Bustamante, P., 2015b. Persistent organic pollutants in a marine bivalve on the Marennes-Oléron Bay and the Gironde Estuary (French Atlantic Coast)-part 1: bioaccumulation. Sci. Total Environ. 514, 500-510.

Luna-Acosta, A., Bustamante, P., Thomas-Guyon, H., Zaldibar, B., Izagirre, U., Marigómez, I., 2017. Integrative biomarker assessment of the effects of chemically and mechanically dispersed crude oil in Pacific oysters, Crassostrea gigas. Sci Total Environ. 598, 713-721.

Luna-Gonzalez, A., Maeda-Martinez, A.N., Vargas-Albores, F., Ascencio-Valle, F., RoblesMungaray, M., 2003. Phenoloxidase activity in larval and juvenile homogenates and adult plasma and haemocytes of bivalve molluscs. Fish Shellfish Immunol. 15, 275-282.

Malanga, C., Young, S.I., 1978. The metabolic fate of dopamine in the ciliated gill epi thelium of bivalve molluscs. J. Comp. Biochem. Physiol. 60C, 129-136.

Manahan, S., 2003. Toxicological Chemistry and Biochemistry. 425 Lewis Publishers, Boca Ratón.

Marie, B., Joubert, C., Tayalé, A., Zanella-Cléon, I., Belliard, C., Piquemal, D., CochennecLaureau, N., Marin, F., Gueguen, Y., Montagnani, C., 2012. Different secretory repertoires control the biomineralization processes of prism and nacre deposition of the pearl oyster shell. Proc. Natl. Acad. Sci. 109, 20986-20991.

Martin-Gomez, L., Villalba, A., Abollo, E., 2012. Identification and expression of immun genes in the flat oyster Ostrea edulis in response to bonamiosis. Gene 492, 81-93.

Maruyama, N., Etoh, H., Sakata, K., Ina, K., 1991. Studies on phenoloxidase from Mytilu. edulis associated with adhesion. Agric. Biol. Chem. 55, 2887-2889.

Matoba, T., Kumagai, A.Yamamoto, Yoshitsu, H., Sugiyama, M., 2006. Crystallographic Evidence That the Dinuclear Copper Center of Tyrosinase Is Flexible during Catalysis. Biol. Chem. http://dx.doi.org/10.1074/jbc.M509785200.

Matozzo, V., Bailo, L., 2015. A first insight into haemocytes of the smooth venus clam Callista chione. Fish Shellfish Immunol. 42, 494-502.

Mayer, A.M., 2006. Polyphenol oxidases in plants and fungi: going places? A review. Phytochemistry 67, 2318-2331.

Milinkovitch, T., Bustamante, P., Huet, V., Reigner, A., Churlaud, C., Thomas-Guyon, H., 2015a. In situ evaluation of oxidative stress and immunological parameters as ecotoxicological biomarkers in a novel sentinel species (Mimachlamys varia). Aquat. Toxicol. 161, 170-175.

Milinkovitch, T., Geraudie, P., Camus, L., Huet, V., Thomas-Guyon, H., 2015b. Biomarker modulation associated with marine diesel contamination in the Iceland scallop (Chlamys islandica). Environ. Sci. Pollut. Res. 22, 19292-19296.

Mouneyrac, C., Buffet, P.E., Poirier, L., Zalouk-Vergnoux, A., Guibbolini, M., Faverney, C.R.D., Gilliland, D., Berhanu, D., Dybowska, A., Châtel, A., Perrein-Ettajni, H., Pan, J.F., Thomas-Guyon, H., Reip, P., Valsami-Jones, E., 2014. Fate and effects of metalbased nanoparticles in two marine invertebrates, the bivalve mollusc Scrobicularia plana and the annelid polychaete Hediste diversicolor. Environ. Sci. Pollut. Res. 21, 7899-7912.

Muñoz, P., Meseguer, J., Esteban, M.A., 2006. Phenoloxidase activity in three commercial bivalve species: changes due to natural infestation with Perkinsus atlanticus. Fish Shellfish Immunol. 20, 12-19.

Nagai, K., Yano, M., Morimoto, K., Miyamoto, H., 2007. Tyrosinase localization in mollusc shells. J. Comp. Biochem. Physiol. 146B, 207-214.

Pang, Q., Zhang, S., Shi, X., Su, F., Wu, D., 2005. Purification and characterisation of phenoloxidase from amphioxus Branchiostoma belcheri tsingtauense. Fish Shellfish Immunol. 19, 139-148.

Pearse, A.G.E., 1985. Histochemistry: Theoretical and Applied. Vol. 2. Churchill Livingstone, Edinburgh, pp. 441-1055. 
Pelmont, J., 1995. Enzymes - Catalyseurs du Monde Vivant. Grenoble Sciences, Grenoble (1039 p).

Peter, R., Raftos, D.A., 2003. The role of phenoloxidase suppression in QX disease outbreaks among Sydney rock oysters (Saccostrea glomerata). Aquaculture 223 (1-4).

Pfaff, M.W., 2001. A new mathematical model for relative quantification in real-time RTPCR. Nucleic Acids Res. 29, e45.

Pipe, R.-K., Coles, J.-A., Carissan, F.-M.-M., Ramanathan, K., 1999. Copper induced immunomodulation in the marine mussel, Mytilus edulis. Aquat. Toxicol. 46, 43-54.

Raftos, D.A., Kuchel, R., Aladaileh, S., Butt, D., 2014. Infectious microbial diseases and host defense responses in Sydney rock oysters. Front. Microbiol. 5, 135.

Renault, T., Faury, N., Barbosa-Solomieu, V., Moreau, K., 2011. Suppression substractive hybridisation (SSH) and real time PCR reveal differential gene expression in the Pacific cupped oyster, Crassostrea gigas, challenged with Ostreid herpesvirus 1. Dev. Comp. Immunol. 35, 725-735.

Renwrantz, L., Schmalmack, W., Redel, R., Friebel, B., Scneeweib, H., 1996. Conversion of phenoloxidase and peroxidase indicators in individual haemocytes of Mytilus edulis specimens and isolation of phenoloxidase from haemocyte extract. J. Comp. Biochem. Physiol. 165B, 647-658.

Richard, G., Le Bris, C., Guérard, F., Lambert, C., Paillard, C., 2015. Immune responses of phenoloxidase and superoxide dismutase in the Manila clam Venerupis philippinarum challenged with Vibrio tapetis - part II: combined effect of temperature and two $V$. tapetis strains. Fish Shellfish Immunol. 44, 79-87.

Riley, P., 1997. Melanin. Int. J. Biochem. Cell Biol. 29, 1235-1239.

Schosinsky, K.-H., Lehmann, H.-P., Beeler, M.-F., 1974. Measurement of ceruloplasmin from its oxidase activity in serum by use of o-dianisidine dihydrochloride. Clin. Chem. 20, 1556-1563.

Simpson, B., Gagne, N., Ashie, I.-N.-A., Noroozi, E., 1997. Utilization of chitosan for preservation of raw shrimp (Pandalus borealis). Food Biotechnol. 11, 25-44.

Smith, L., Stotz, E., 1954. Purification of cytochrome c oxidase. J. Biol. Chem. 209, 819-828.

Solomon, E.I., Sundaram, U.M., Machonkin, T.E., 1996. Multicopper oxidases and oxigenases. Chem. Rev. 96, 2563-2606.

Terenius, O., Bettencourt, R., Lee, S.Y., Söderhäll, K., Faye, I., 2007. RNA interference of hemolin causes depletion of phenoloxidase activity in Hyalophora cecropia. Dev. Comp. Immunol. 31, 571-575.

Thiagarajan, R., Gopalakrishnan, S., Thilagam, H., 2006. Immunomodulation in the marine green mussel Perna viridis exposed to sub-lethal concentrations of $\mathrm{Cu}$ and $\mathrm{Hg}$. Arch. Environ. Contam. Toxicol. 51, 392-399.

Thomas-Guyon, H., Gagnaire, B., Bado-Nilles, A., Bouilly, K., Lapègue, S., Renault, T. 2009. Detection of phenoloxidase activity in early stages of the Pacific oyster Crassostrea gigas (Thunberg). Dev. Comp. Immunol. 33, 653-659.

Timothy, J.G., Helbig, K., Speck, P., Raftos, A.D., 2016. Primed for success: oyster parents treated with poly(I:C) produce offspring with enhanced protection against Ostreid herpesvirus type I infection. Original research article. Mol. Immunol. 78, 113-120.

Waite, J., Wilbur, K., 1976. Phenoloxidase in the periostracum of the marine bivalve Modiolus demissus Dillwyn. J. Exp. Zool. 195, 359-367.

Walker, J., Ferrar, P., 1998. Diphenol oxidases, enzyme-catalysed browning and plant disease resistance. Biotechnol. Genet. Eng. Rev. 15, 457-498.

Wang, L., Yue, F., Song, X., Song, L., 2015. Maternal immune transfer in mollusc. Dev. Comp. Immunol. 48, 354-359.

Xing, J., Lin, T., Zhan, W., 2008. Variations of enzymes activities in the haemocytes of scallop Chlamys farreri after infection with the acute virus necrobiotic virus (AVNV). Fish Shellfish Immunol. 25, 847-852.

Zhang, C., Xie, L., Huang, J., Chen, L., Zhang, R., 2006. A novel putative tyrosinase involved in periostracum formation from the pearl oyster (Pinctada fucata). Biochem. Biophys. Res. Commun. 342, 632-639.

Zhao, M., Söderhäll, I., Park, J.W., Ma, Y.G., Osaki, T., Ha, N.C., Wu, C.-F., Söderhäll, K., Lee, B.L., 2005. A novel 43-kDa protein as a negative regulatory component of phenoloxidase-induced melanin synthesis. J. Biol. Chem. 280, 24744-24751.

Zhao, P., Li, J., Wang, Y., Jiang, H., 2007. Broad-spectrum antimicrobial activity of the reactive compounds generated in vitro by Manduca sexta phenoloxidase. Insect Biochem. Mol. Biol. 37, 952-959.

Zhou, Z., Ni, D., Wang, M., Wang, L., Shi, X., Wang, L., Yue, F., Liu, R., Song, L., 2012. The phenoloxidase activity and antibacterial function of a tyrosinase from scallop Chlamys farreri. Fish Shellfish Immunol. 33, 375-381. 